\title{
EL PRECERÁMICO EN QOTAMISA PAMPA - PUNAS DE HUANCAPI- VICTOR FAJARDO - AYACUCHO
}

\author{
Sonia LaURENTE PaLomino \\ UnIVERSIDAd NACIONAL SAN CRISTÓbaL DE HUAMANGA \\ soili_frien@outlook.com \\ JHON RenÉ HuAMANí DIAZ \\ Universidad NACIONAL DE SAN CRISTÓBAL DE HUAMANGA \\ loehjr@hotmail.com
}

\section{RESUMEN}

El presente trabajo está basado en el estudio del sitio arqueológico de Qotamisa Pampa a partir de una prospección arqueológica sistemática, teniendo en cuenta el paisaje que rodea al sitio. El aspecto que ha sido considerado en el estudio de estas sociedades fueron las armas utilizadas para la cacería (puntas), el análisis sobre la fauna que hasta hoy existe en el sitio y el paisaje en el cual se dan los encuentros entre cazadores y los camélidos. Estos son los indicadores de estas sociedades.

Se pretende caracterizar los paisajes donde se promovieron y materializaron los encuentros entre cazadores y camélidos en el área de Qotamisa Pampa, evaluando los diferentes factores que entran en esta actividad tales como: cazadores, paisaje, camélidos, tecnología, etc.; estas se interrelacionan y confluyen en los escenarios de caza. La elección de esta área para las actividades responde a que esta presenta todas las características necesarias para su elección como paisaje para la ocupación del territorio por parte de los camélidos, dadas ciertas características como son la presencia de agua, pastizales, laderas suaves y roquedales altos. Es por esta razón que Qotamisa Pampa es un caso relevante para la investigación aquí propuesta, de esta manera se va a hacer una investigación superficial y evaluar las características de los paisajes, el material cultural asociado (artefactos líticos y las pinturas rupestres) y otros, y de esta manera pueda sostenerse en los planteamientos de la Arqueología del Paisaje.

Palabras Clave: Precerámico, Qotamisa Pampa, cazadores- recolectores, arte rupestre- puntas de proyectil, material lítico. 


\section{Abstract}

This is based on the study of the archaeological site of Pampa Qotamisa from a systematic archaeological survey, taking into account the landscape surrounding the site. The aspect that has been considered in the study of these societies were the weapons used for hunting (Tips), the analysis of the wildlife that until today exists on the site and the landscape in which encounters between hunters and camelids are given are the indicators of these companies.

Aims to characterize the landscapes where they were promoted and materialized encounters between hunters and camelidaes area Qotamisa Pampa, evaluating the different factors involved in this activity such as (hunters, landscape, camels, technology, etc.), these interrelate and converge in hunting scenarios. The choice of this area for activities responds that this has all the characteristics necessary for election as landscape for the occupation of territory by camelids, given certain characteristics such as the presence of water, grasslands, gentle slopes and high rocky . It is for this reason that Qotamisa Pampa is a case for research proposed here, so make a cursory investigation and evaluate the characteristics of the landscapes, the associated cultural material (lithic artifacts and paintings) and others, so it can be held in the approaches of Landscape Archaeology.

Kerwords: Preceramic, Qotamisa Pampa, hunter-gatherers, projectile points rupestre- art, lithic material.

\section{Aspectos Geográficos}

El área de estudio se localiza a $124 \mathrm{~km}$ al sur de la ciudad de Ayacucho, a una altitud de 4268 m.s.n.m. Políticamente está comprendido dentro de la Carta Nacional del Instituto Geográfico Na-

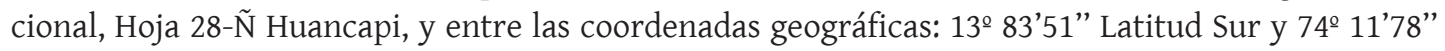
Longitud Oeste. Se encuentra en la jurisdicción del distrito de Huancapi, provincia de Víctor Fajardo y la región de Ayacucho. La provincia de Victor Fajardo por el norte limita con la provincia de Cangallo, por el este limita con las provincias de Vilcashuamán y Sucre, por el sur limita con las provincias de Lucanas y Huancasancos y por el oeste limita con la provincia de Huaytará (Huancavelica) (ver figura 01).

\section{Descripción del Sitio Arqueológico de Qotamisa Pampa}

El sitio arqueológico de Qotamisa Pampa es una planicie ubicada en la puna del distrito de Huancapi, en el lugar se encuentran evidencias culturales de la presencia del hombre que vivió a partir del periodo Lítico hasta inicios del Formativo.

En la superficie del área que fue parte de la prospección se observa una gran cantidad y variedad de tipos de puntas que fueron elaboradas cuidadosamente en distintos tipos de rocas o materia prima.

Estos hombres ocuparon esta área durante el Precerámico, porque presenta características tanto topográficas como inmensas pampas con presencia de agua y pastos naturales para el consumo de los camélidos; también por la presencia de recursos para la explotación y elaboración de sus artefactos y armas tales como las puntas de proyectil. También se tiene la presencia de la fuente de obsidiana cercana de Huancasancos, la cantera de sal líquida de Cachipata y los recursos propios del sitio como los hongos, las aves, los peces y alimentos aptos para el consumo humano. 


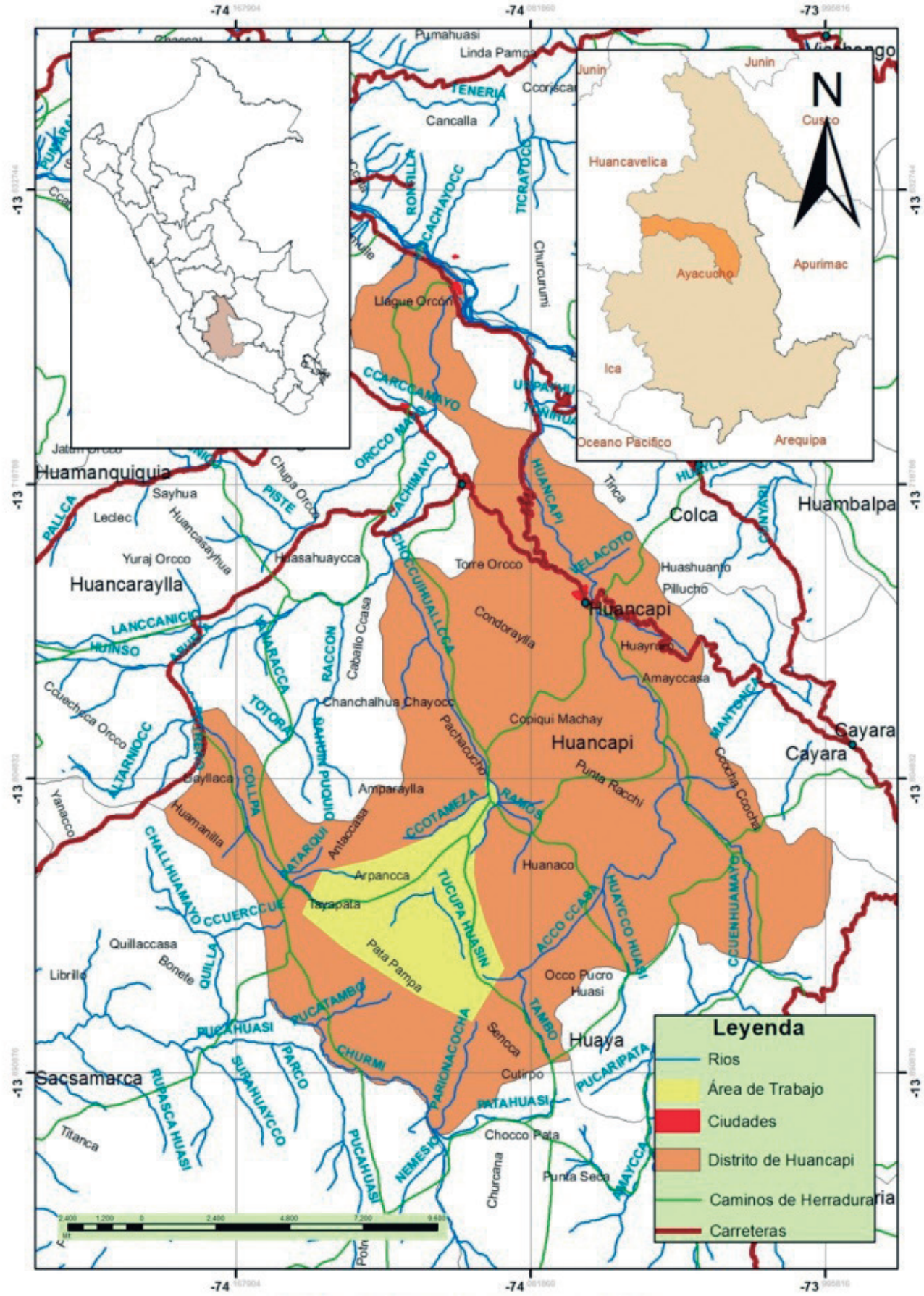

Figura 01.- Mapa de ubicación del sitio arqueológico de Qotamisa Pampa. 


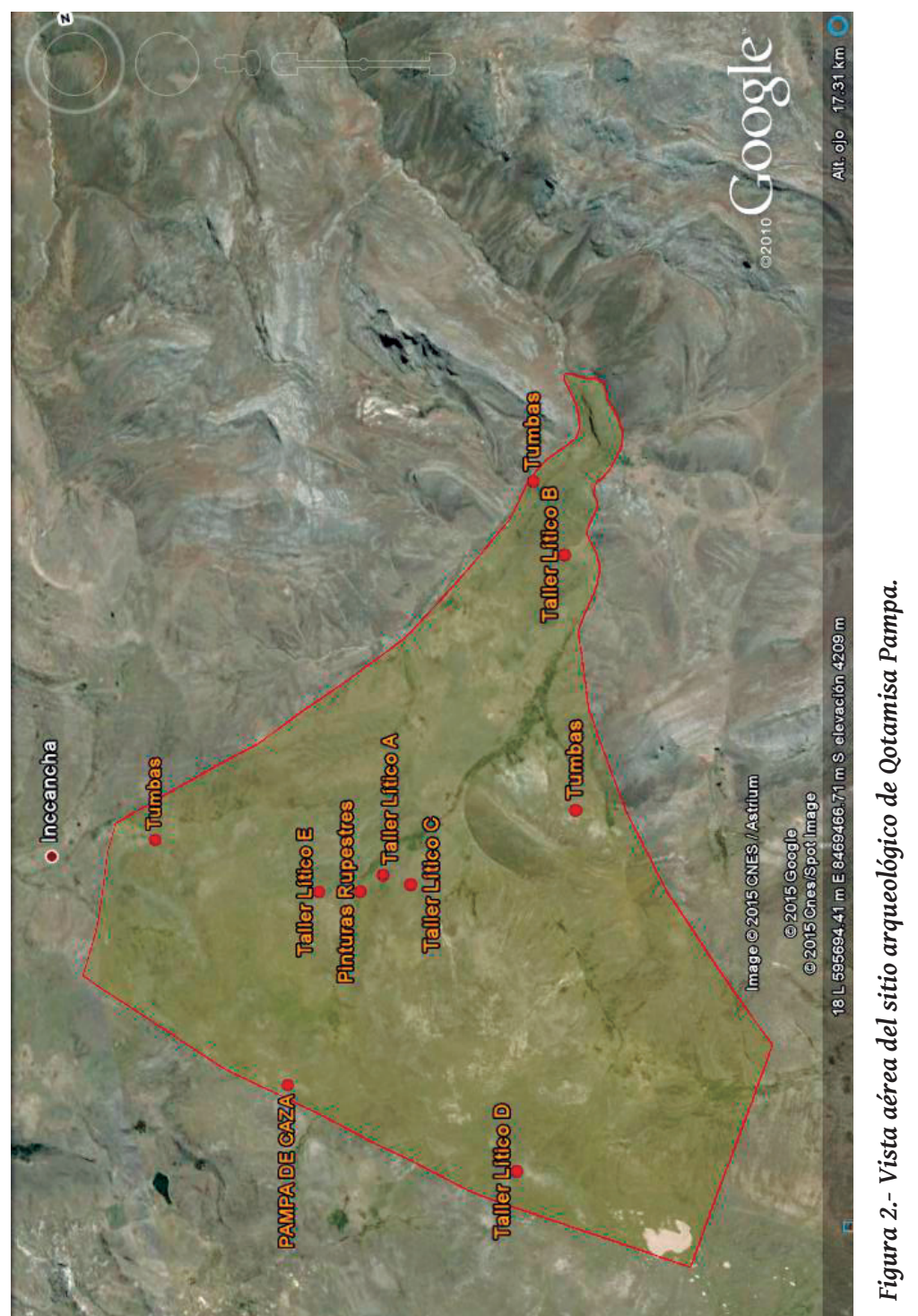




\section{ANTECEDENTES DE INVESTIGACIÓN}

Los trabajos arqueológicos efectuados en el sur de Ayacucho son muy pocos, se tiene referencia del trabajo efectuado en los años 1940 por Dionisio Salas Vitangurt, quien efectúa un recorrido por San Juan de Lucanas, Santa Lucía, Tambo Quemado, Pampa Galeras, Puquio, Huacaña, Oyolo y Parinacochas; e informa de la existencia de varios sitios arqueológicos en todo este territorio: Naupallaqta, Sacsamarca, Huamanmarca, Trigochacra, Cajapata, Ayapata, Quishuarniyucc, Umamarca, Oscconta y Huacramarca.

Durante el 2002 y el 2005 Vivanco menciona para el valle del río Huancapi la existencia del sitio de Ñawpallacta y Raqaraqaypata y que estan asociados a ocupaciones del periodo Intermedio Tardío y el Horizonte Tardio. También menciona a sitios como Tinkaorqo, Wayruro, Orqowasi, Ispaqrumi, Wamanillo y Matiorqo.

Como los últimos estudios realizados en la parte sur de Ayacucho se tiene a los trabajos realizados por Daniel A. Contreras, Nicholas Tripcevich y Yuri Cavero (2012), quienes trabajan en las canteras de obsidiana del tipo Qispisisaq, que está en Huancasancos en el lugar denominado Jichja Parco, donde se registraron 32 pozos de cantera de Obsidiana, con presencia de lascas de producción primaria y nódulos. Por su parte Khinjhe Canchari (2015) hace un estudio sobre el poblado de Raqaraqaypata, especialmente de la arquitectura del Periodo Intermedio Tardío, en donde identifica estructuras circulares asociadas a pasadizos, escalinatas, espacios abiertos. También identifica terraplenes, muros de contención y caminos. Concluye que el patrón arquitectónico responde a razones estratégicas de orden defensivo del Periodo Intermedio Tardío.

Cirilo Vivanco y otros (2015), realizan investigaciones sobre aspectos geográficos, arqueológicos e históricos en Huamanquiquia. Registran un total de 61 sitios entre poblados, aldeas, fortificaciones, aldeas, sitios ceremoniales, entierros, andenerías y corrales, correspondientes a épocas Warpa, Chanka e Inca. Lo más importante es que registran 4 sitios correspondientes al pre cerámico (Winsuqasa, Uchuy Kumun Nawi, Kampanayuq y Pichinchuyuq Machay), se tratan de cuevas que se usaron como campamento, ubicadas en la puna.

\section{Intervenciones Arqueológicas en Qotamisa Pampa}

Teniendo en cuenta la extensión del área a investigar se evaluó el área a estudiar y su aprovechamiento por los cazadores. El área de estudio es muy relevante por las relaciones que existieron durante el Precerámico entre humanos y el paisaje; las características del paisaje con distintas características ambientales, hídricas, presencia de recursos animales y vegetales, etc., es lo que los hombres aprovecharon a lo largo de su estadía en este sitio.

Los trabajos de campo comenzaron primero con el mapeo del sitio (entrevista al señor Julio Huamaní Fernández, quien nos dio los datos y nos mostró algunos artefactos que eran procedentes del sitio), luego se procedió a elaborar el mapa de delimitación del sitio. Luego se hizo la descripción y el registro (gráfico y fotográfico) de las evidencias culturales.

Es preciso mencionar que cada evidencia cultural importante tales como artefactos (puntas, raspadores, raederas, cuchillos y otros), talleres, corrales, pinturas rupestres, tumbas, etc; todos fueron registrados con una coordenada del GPS. Luego se realizó un croquis del sitio viendo la distribución de los elementos culturales. Después se procedió con el registro fotográfico, gráfico y una descripción detallada de los elementos culturales y la recolección superficial del material diagnóstico lítico. Cada evidencia se recolectó en bolsas con sus respectivas etiquetas incluyendo la coordenada UTM. 


\section{Descripción de las Evidencias Materiales}

\section{Arquitectura}

La Arquitectura encontrada en Qotamisa Pampa fue registrada viendo el tipo al que pertenecen, por ejemplo se tienen corrales, estructuras funerarias y talleres. Para el registro de la arquitectura se tomó en cuenta lo siguiente: primero se ubicó la arquitectura, luego se puso la coordenada UTM, y se hizo una descripción detallada del tipo de arquitectura y de los elementos asociados a este, Posteriormente se tomó las respectivas fotografías usando las escalas, y finalmente se hizo un dibujo a escala de algunas arquitecturas resaltantes.

Corrales: Los corrales son estructuras de planta rectangular o circular que formaba espacios cerrados o abiertos, y servía para la crianza de camélidos (Echevarría 2011: 115). En Qotamisa Pampa se tiene el registro de corrales de plantas circulares, con medidas que varían desde los 5 metros de diámetro hasta las más grandes que llegan a tener más de 35 metros de diámetro, están elaborados con piedras grandes alargadas que estuvieron paradas; y el otro tipo de construcción se trata de pircas para los corrales pequeños. La materia prima utilizada son rocas volcánicas que son del mismo lugar. Al interior de estos corrales se han registrado algunas puntas unas íntegras y la mayoría fragmentadas por lo general en la parte distal de estos artefactos (ver Figura 3 y 4 ).

Los corrales registrados se ubican en las coordenadas UTM 594309.99 E, 8469250.67 S y a una altitud de 4282 m.s.n.m .

Estructuras Funerarias: En el área se tienen varias estructuras funerarias, asociadas a materiales líticos tales como desechos de talla, puntas de proyectil y otros. En las paredes de estas se observan restos de pictografías de color rojo, conformados por líneas alargadas de aproximadamente $20 \mathrm{~cm}$ de largo, generalmente en el acceso de las tumbas. Fueron elaboradas con piedra unida con mortero de barro compacto, son de mampostería ordinaria. La forma de estas estructuras son ovoidales, redondeados y ligeramente rectangulares. El vano de estas estructuras son rectangulares y ovaladas.

Las piedras empleadas en la construcción son lajas alargadas de diferentes tamaños provenientes del mismo lugar, se tratan de rocas volcánicas. La parte interna de estas estructuras presentan un tratamiento especial, el piso tiene un revestimiento de piedras en toda la estructura. En algunos de estos se encontraron asociados restos óseos como cráneos y huesos largos. Algunas estructuras están en regular estado de conservación, pero otras están en un muy mal (ver figura 5 a figura 8).

Talleres: Los talleres son espacios en donde se aprovecharon nódulos para la elaboración de los diferentes artefactos, estos espacios son de diferentes tamaños. En Qotamisa Pampa se pueden ver talleres grandes y medianos. En los talleres más extensos pueden notarse áreas de mayor actividad y la concentración de desechos es mucho más densa. En función de ello, las técnicas de talla que utilizaron para la elaboración de artefactos fue la percusión y el retoque.

En Qotamisa Pampa los talleres varían de tamaño de $30 \mathrm{~m}^{2}$ a $120 \mathrm{~m}^{2}$. En estas se registraron artefactos líticos tales como puntas, raspadores, raederas, cuchillos, desechos de talla, lascas y láminas. Estas están elaboradas en su gran mayoría en obsidiana, y también podemos encontrar en basalto y en cuarzo en un menor porcentaje. Por causa de las lluvias estos artefactos han sido arrasados hacia la parte inferior del taller.

En estos talleres se ve una clara evidencia de que los hombres que habitaron, usaron este espacio para la fabricación de sus artefactos, ya que en la superficie de esta se ve la presencia de una cantidad considerable de desechos de talla, algunas preformas de punta, y asociadas a esta se tiene cantos rodados que fueron usados como percutores para la elaboración de sus útiles. En caso del taller D, muestra 


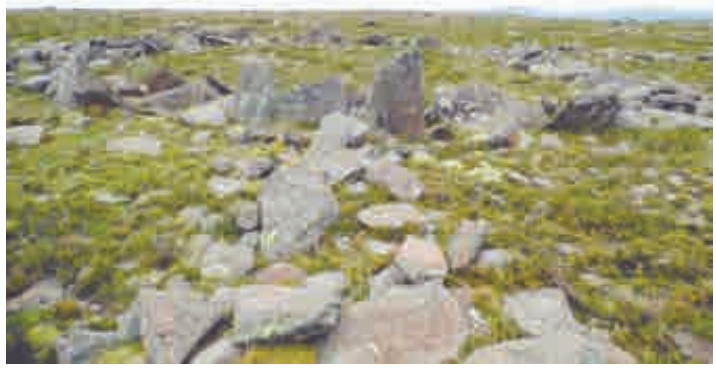

Figura 3: Vista de corrales de formas circulares.

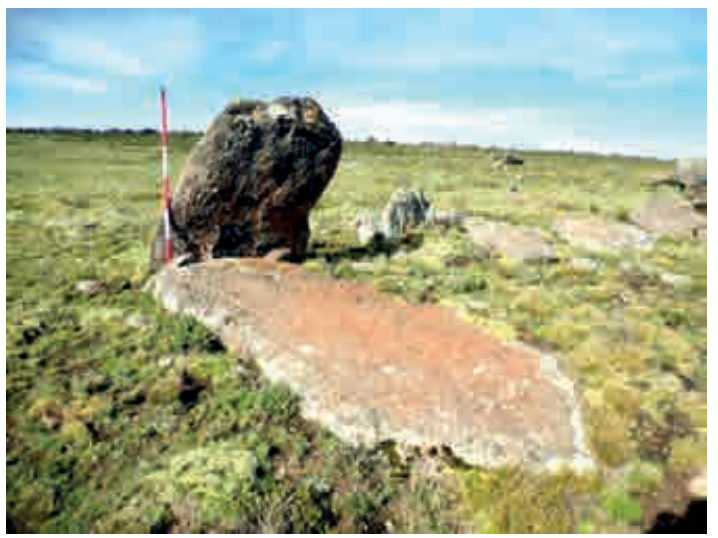

Figura 4: Vista de las piedras que conforman los corrales.

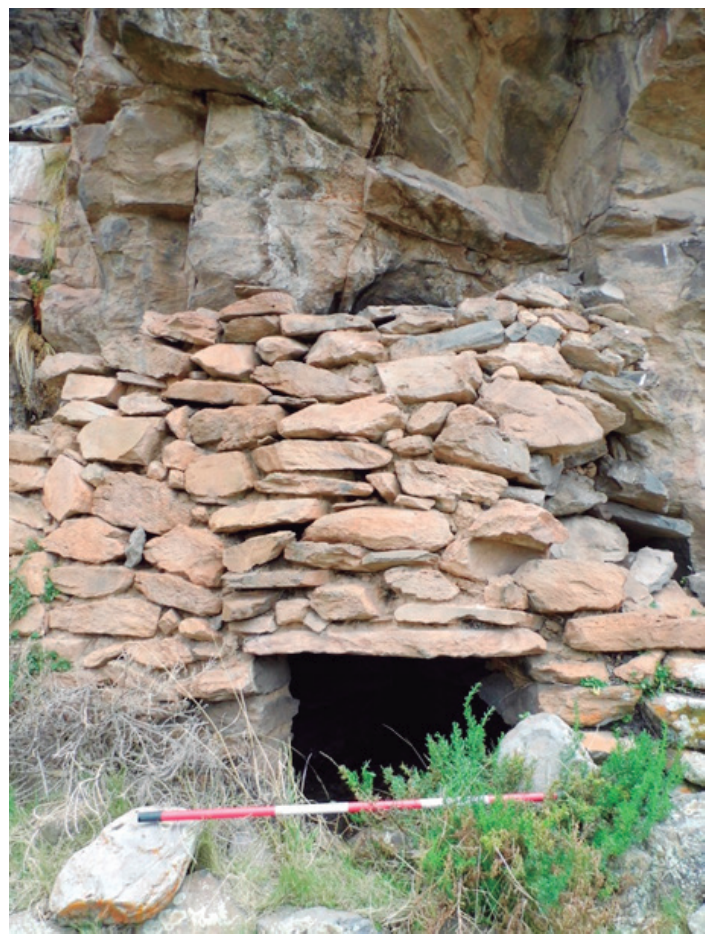

Foto 5: Vista de una estructura funeraria elaborada con piedra y con mortero de barro con acceso cuadrangular.

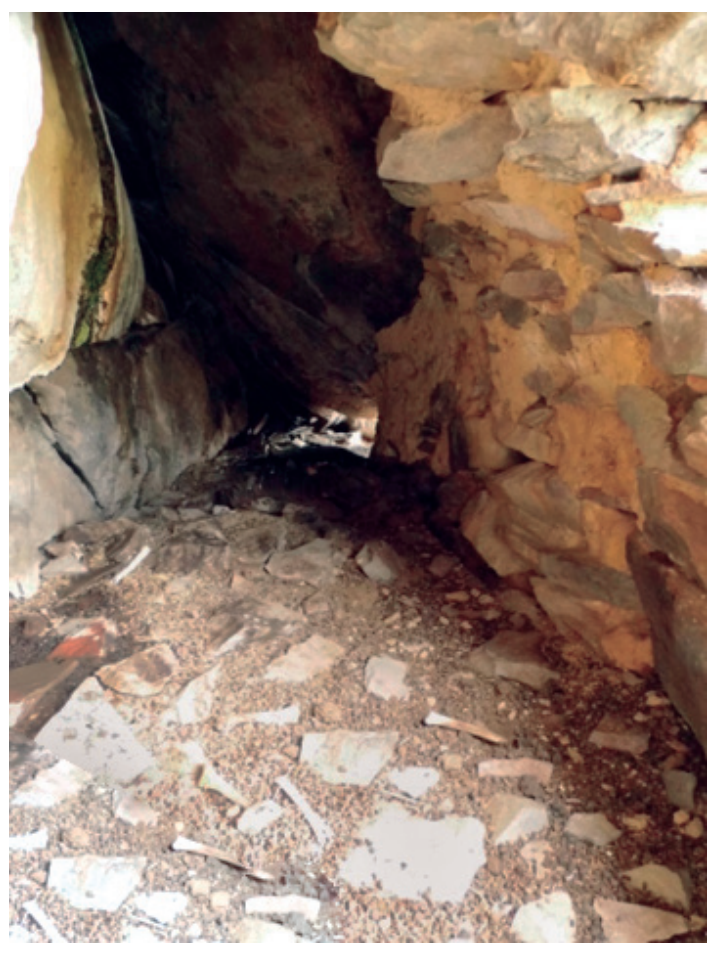

Figura 6: Vista interna de una estructura funeraria elaborada con piedra $y$ con mortero de barro. 


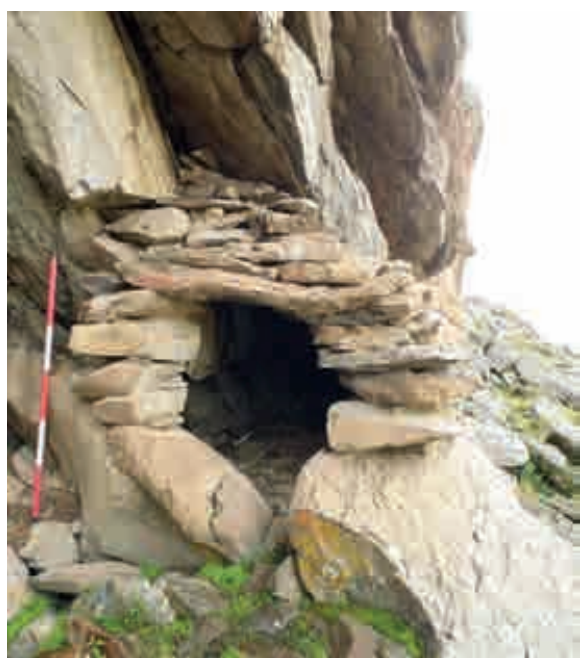

Figura 7: Vista de una estructura funeraria elaborada con piedra y con mortero de barro en acceso ovalado.

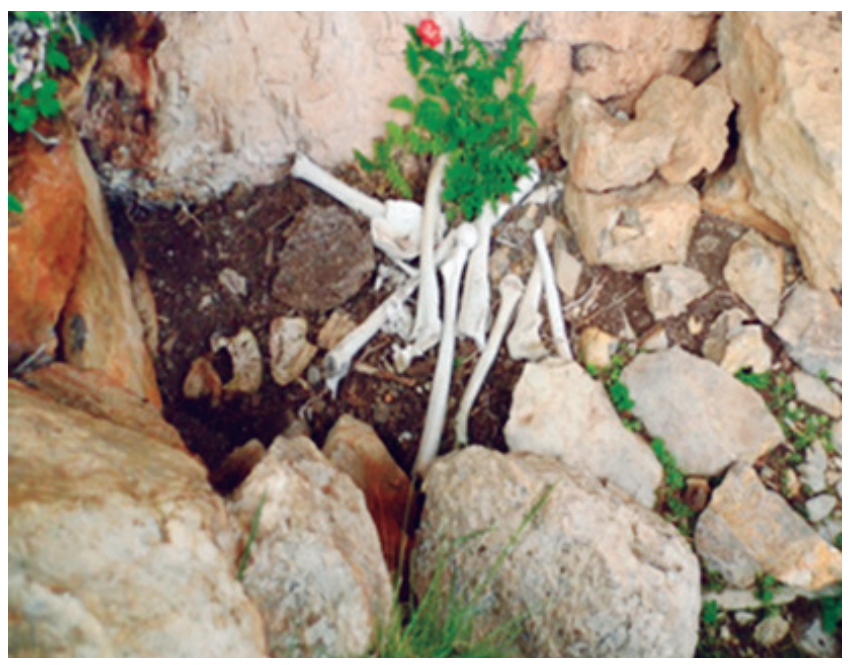

Figura 8: Vista de restos óseos al interior de una estructura en mal estado de conservación.

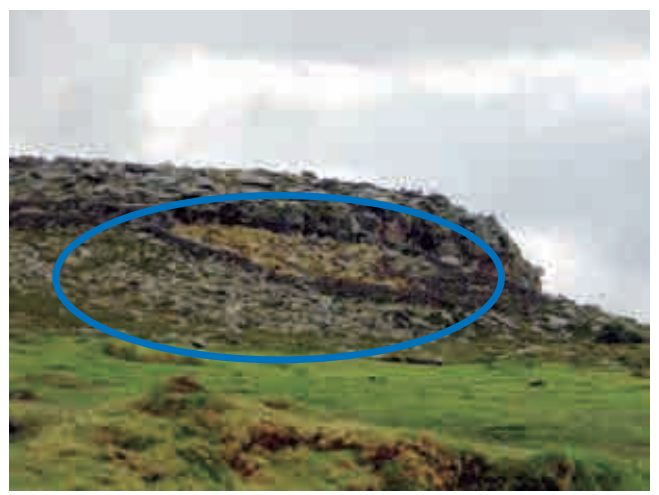

Figura 09: Vista panorámica del taller A

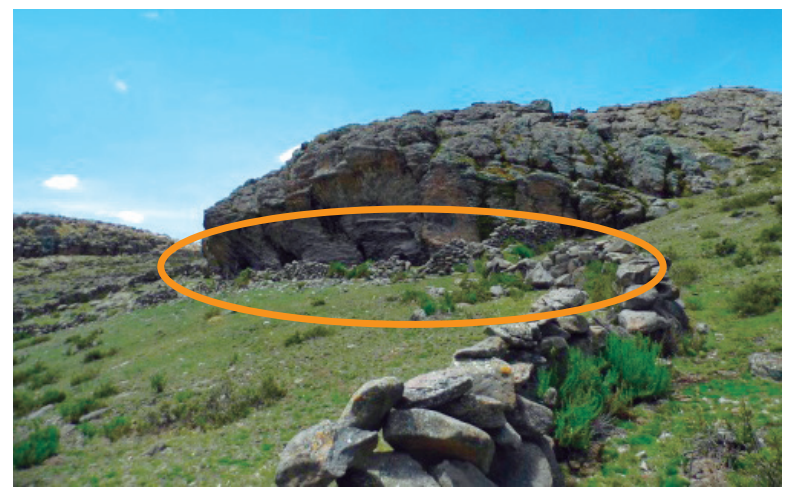

Figura 10: Vista panorámica del Taller B.

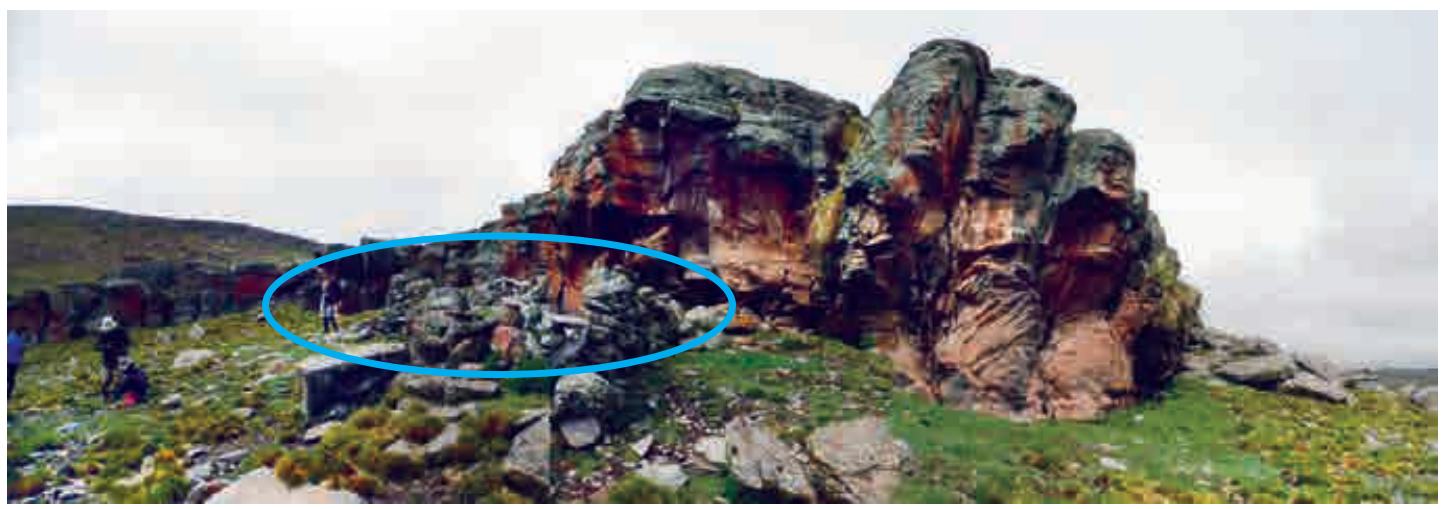

Figura 11: Vista panorámica del Taller C. 
que en esta probablemente habitaron ya que se tiene a diferencia de las otras, una mayor concentración de raspadores, cuchillos y raederas y que probablemente estas fueron usadas para el tratamiento tanto de la carne como de las pieles de los camélidos (ver figura 9 a Figura 13).

\section{Pinturas Rupestres}

Las pinturas rupestres registradas en el sitio son de color rojo, los diseños que presentan se tratan de motivos en forma de cruces, soles, puntos, líneas, personas con flechas, camélidos, y el resto se tratan de motivos abstractos; no se puede definir bien la forma que tienen o a que representan. Esas pinturas rupestres están asociadas a talleres líticos, y también a materiales líticos; generalmente estas se encuentran en los roquedales. La mayoría de las pinturas rupestres se encuentran en un muy mal estado de conservación debido a los factores climáticos tales como la humedad y las lluvias, en algunas ocasiones algunas rocas han cedido por la excesiva humedad y otras ya se están borrando.

Las pinturas rupestres registradas en Qotamisa Pampa, fueron hechas con la técnica de un solo trazo y otras muestras presentan el relleno, la técnica de un solo trazo presenta un solo color, con líneas semidelgadas y también los de líneas gruesas aparentemente pastosas (Castillo 2006: 23). Los paneles varían en tamaño, podemos encontrar paneles de $0.10 \times 0.10 \mathrm{~m}, 0.20 \times 0.20 \mathrm{~m}, 0.20 \times 0.40 \mathrm{mts}$, $1.20 \times 0.50 \mathrm{~m}$. (ver figura 14 a figura 19).

\section{Material Lítico}

\section{Núcleo}

Se cuenta con 4 ejemplares, se tratan de núcleos mixtos, de los cuales 1 es en obsidiana con una longitud de $4.8 \mathrm{~cm}$. y $3 \mathrm{~cm}$ de ancho; de forma alargada, presenta negativos de diferentes formas y en múltiples direcciones. 2 ejemplares son de basalto, la longitud es de $7.5 \mathrm{~cm}$ por $8 \mathrm{~cm}$ y $6 \mathrm{~cm}$ por $5.8 \mathrm{~cm}$ de ancho, de forma globular, presenta negativos en múltiples direcciones. El último es de shert, tiene una longitud de $4.5 \mathrm{~cm}$ y un ancho de $3.1 \mathrm{~cm}$, de forma globular con negativos en múltiples direcciones. Presentan una cantidad de córtex, el plano de percusión es natural. En el núcleo de obsidiana se observa con mayor claridad las ondas de propagación del golpe y las nervaduras.

Los promedios de los ángulos de las cornisas son bastante homogéneos, variando generalmente entre $80^{\circ}$ y $120^{\circ}$, mientras que los promedios de los ángulos aristas generalmente oscilan entre $60^{\circ}$ y $100^{\circ}$. Esto implica que los núcleos fueron abandonados cuando todas las cornisas agudas fueron agotadas, luego de obtener al menos de 10 a 30 lascas, dejando un porcentaje de córtex generalmente de un 5\% (aunque puede llegar hasta 35\%). La correspondencia entre dichos ángulos y el número de negativos es evidente, en donde a mayor número de negativos, es de esperar ángulos de cornisas y de aristas más obtusas. La reducción de los núcleos fue bastante escasa, ya que se trató de obtener el máximo provecho de cada bloque, lo que se evidencia en la yuxtaposición de los negativos. Los núcleos fueron desbastados con percutor duro, mientras que la dirección de las extracciones en 3 núcleos de tipo multidireccional, y de tipo bidireccional es en 1 núcleo. No se registraron núcleos con dirección unidireccional, (ver figura 20).

\section{DeRIVAdos de Núcleo}

Los derivados de núcleo son un componente de la industria de la Piedra Tallada, son las astillas desprendidas o extraídas del núcleo pudiendo ser lascas, láminas o desechos de talla, también se le conoce como el proceso de debitage o reducción de la materia prima. Estos desprendimientos, ya sean 


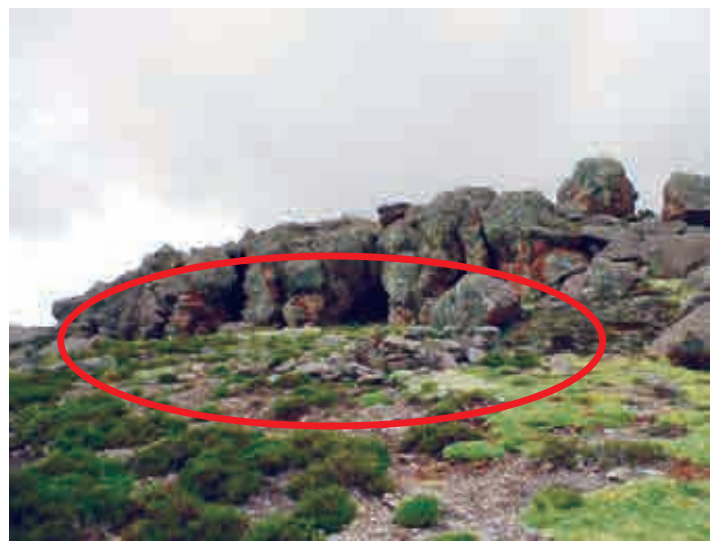

Figura 12: Vista panorámica del Taller D.

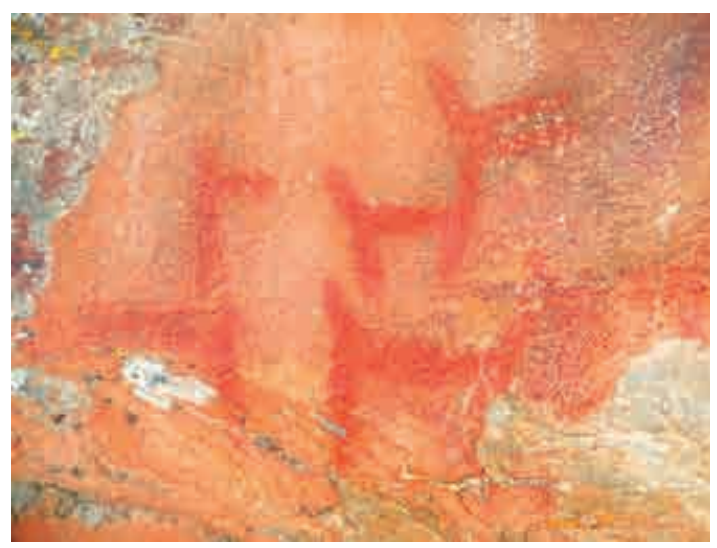

Figura 14: Panel en detalle con representación de camélidos.

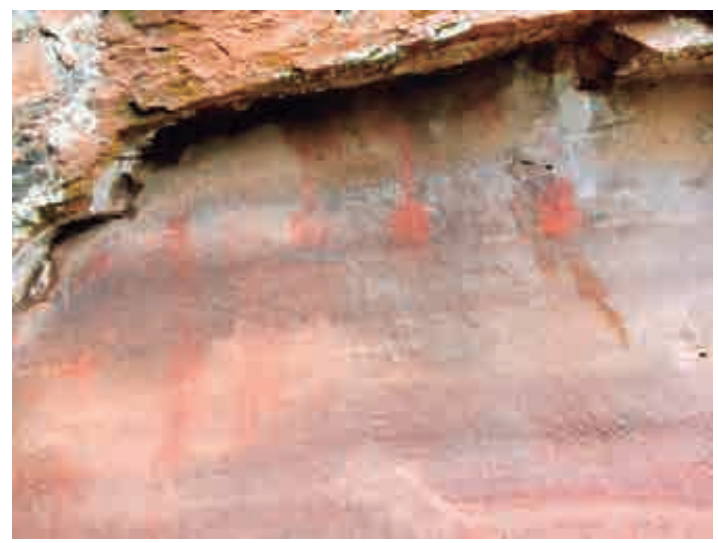

Figura 17: Panel en detalle con representación de motivos abstractos a manera de líneas y puntos.

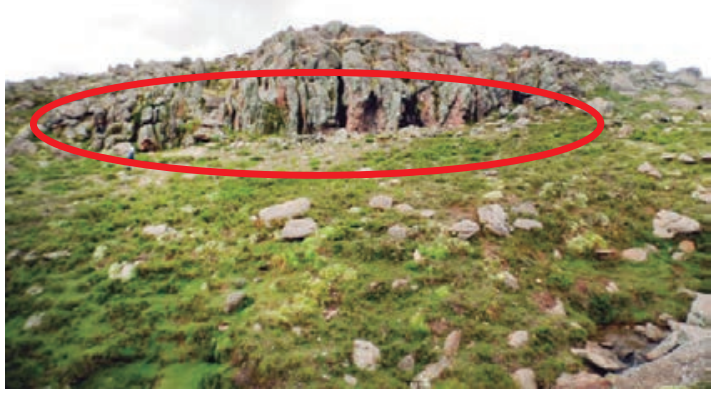

Figura 13: Vista panorámica del Taller E.

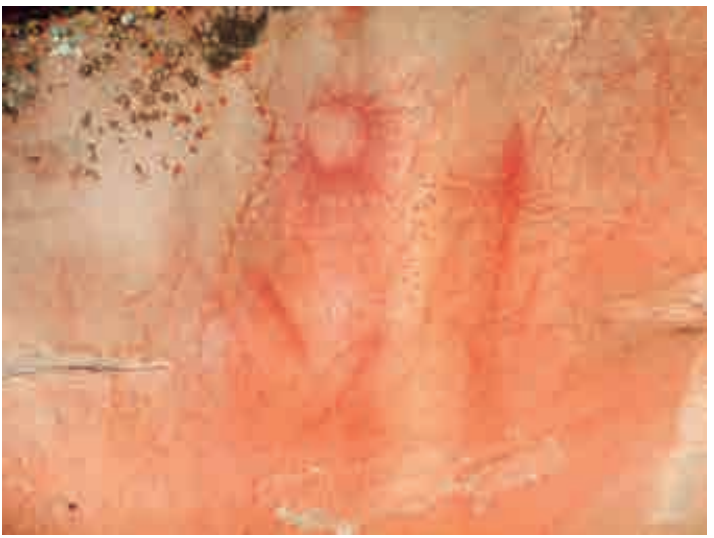

Figura 15: Panel en detalle con representación de líneas delgadas, motivos abstractos y motivo parecido al sol.

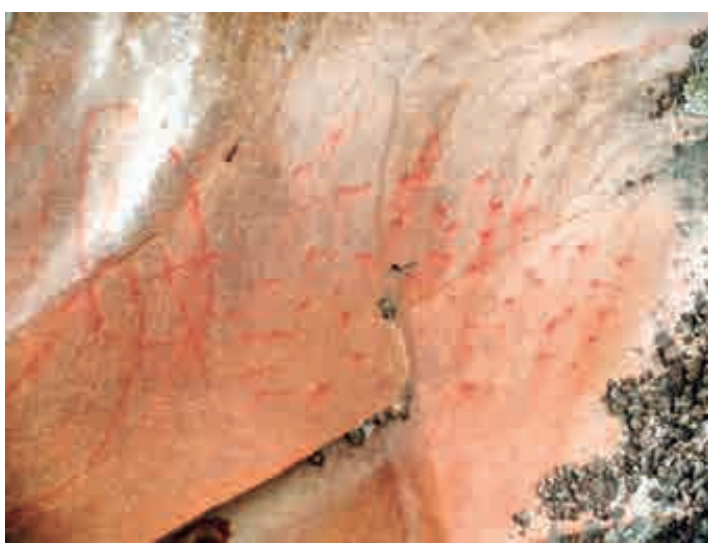

Figura 16: Panel en detalle con representación de frutos colgantes. 
lascas o láminas, presentan una cara dorsal que está formada por el córtex que es la superficie natural de la roca, se ve las nervaduras y el talón que ha sido el punto de percusión, también presenta la cara dorsal en el que se observan las ondas de propagación del golpe y el bulbo de percusión. Dentro de este grupo se tiene:

LASCAS. Como lascas se conocen a la porción de roca que ha sido extraída de un núcleo, ya sea por la técnica de percusión o por presión, en el cual el ancho es dos veces que el largo. Por lasca de manera general se entiende como la porción de una roca que ha sido extraída de un núcleo o de una materia prima que ha sido desprendida ya sea por la técnica de percusión o por presión, en el cual el ancho es el doble del largo. Las lascas se separaron por tipo de materia prima.

LASCAS SIN MODIFICACIÓN. Dentro de este grupo se encuentran todos los desprendimientos o astillas que después de haber sido extraídas del núcleo no fueron modificados, pero posiblemente fueron usados en alguna actividad. Se cuenta con un total de 6 muestras de las cuales 5 son de obsidiana de color negro, y uno de basalto, las medidas varían de $2.7 \mathrm{~cm}$ a $1.9 \mathrm{~cm}$ de largo, $2.2 \mathrm{~cm}$ a $2.8 \mathrm{~cm}$ de ancho y 0.4 a $0.6 \mathrm{~cm}$ de espesor (ver figura 21).

LÁMINAS. Es una porción de roca extraída de un núcleo, ya sea por percusión o por presión en el cual el largo es dos veces más que el ancho. Por lámina de manera general se entiende como un desprendimiento que se obtiene a partir de un núcleo o de una materia prima, la longitud de esta es 2 veces más que el ancho.

LAMINAS SIN MODIFICACIÓN. Se trata de desprendimientos o astillas que después de haber sido desprendidos del núcleo, estos fragmentos no fueron modificados. Las láminas sin modificación son aquellas láminas que no han sido modificadas, algunos se usaron tal como se ha desprendido del núcleo, otros son solo desechos.

Se cuenta en total con 29 fragmentos de láminas de las cuales 13 son de obsidiana de color negro, 1 en obsidiana roja, 6 en basalto, 4 en cuarzo, 3 en arenisca y 1 en riolita. Dentro de este grupo se encuentran láminas primarias y láminas secundarias. Las medidas varían de $8.8 \mathrm{~cm}$ a $2.2 \mathrm{~cm}$ de largo, de $4.6 \mathrm{~cm}$ a $1 \mathrm{~cm}$ de ancho, y de 0.3 a $1.5 \mathrm{~cm}$ de espesor. La mayoría de las láminas presentan las ondas de percusión superficial y dos fragmentos presentan las ondas de percusión profunda, la mayoría no presentan córtex en la superficie, o solo presentan en un pequeño porcentaje ya que se tratan de láminas secundarias, presentan negativos y todas tienen un punto de percusión (ver figuras 22 y 23).

LASCAS Y LÁMINAS CON MODIFICACIÓN. Las lascas y láminas con modificación son aquellos desprendimientos o astillas que han sido desprendidos del núcleo, y que estos fueron modificados con un trabajo secundario para darle una utilidad. Dentro de este grupo se tiene:

PUNTAS. Se tratan de artefactos que se caracterizan por tener un extremo penetrante formado por dos bordes convergentes, puede ser elaborado a partir de una lasca o lámina: "Son piezas realizadas sobre lascas, soportes laminares y conformadas por retoque bifacial generalmente plano... también está definido en un sentido morfológico y funcional" (Juan 2008: 129-130). Las puntas tienen "un ápice y un encuentro de dos filos, también tiene un extremo penetrante definido por dos lados convergentes" (Winchkler, 2006). Las puntas presentan talla bifacial o en ambas caras con retoques, estos retoques pueden ser los que cubren o invaden el artefacto. Para la clasificación tipológica se tuvo en cuenta a Merino (1994), Salcedo (1997), Juan (2008), y otros.

Dentro de la tipología de puntas para el área de investigación se identificó 186 especímenes de este artefacto, y dentro de estas se encontraron 21 tipos de puntas de proyectil, que han sido separadas por la morfología que tiene el artefacto, esta tipología de puntas se detallará a continuación: 


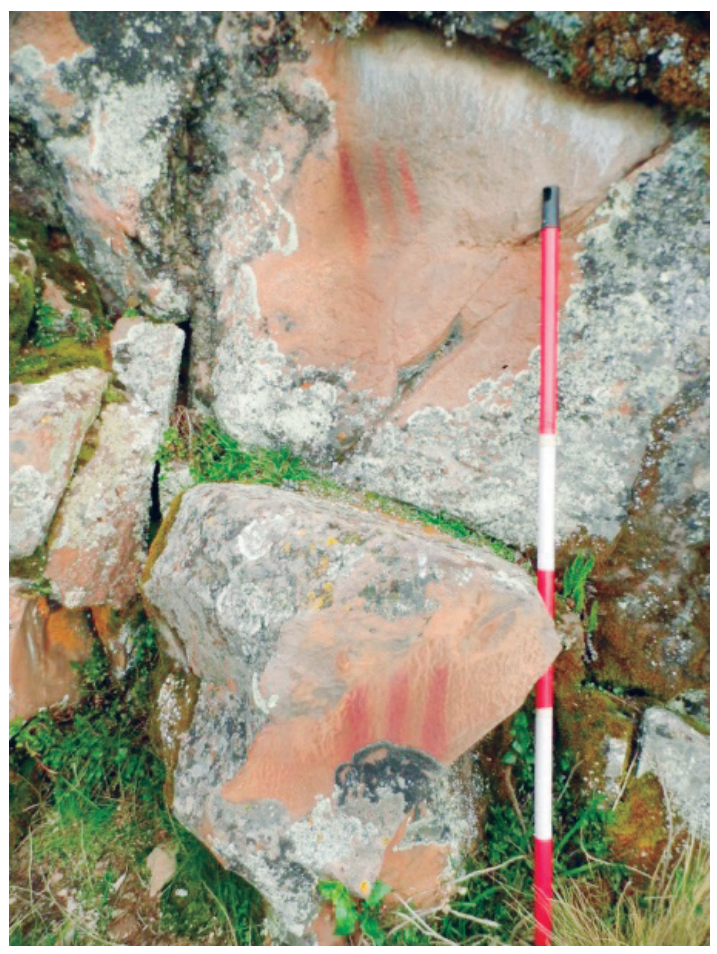

Figura 18: Representación de líneas gruesas, al parecer están hechos con los dedos de las manos.

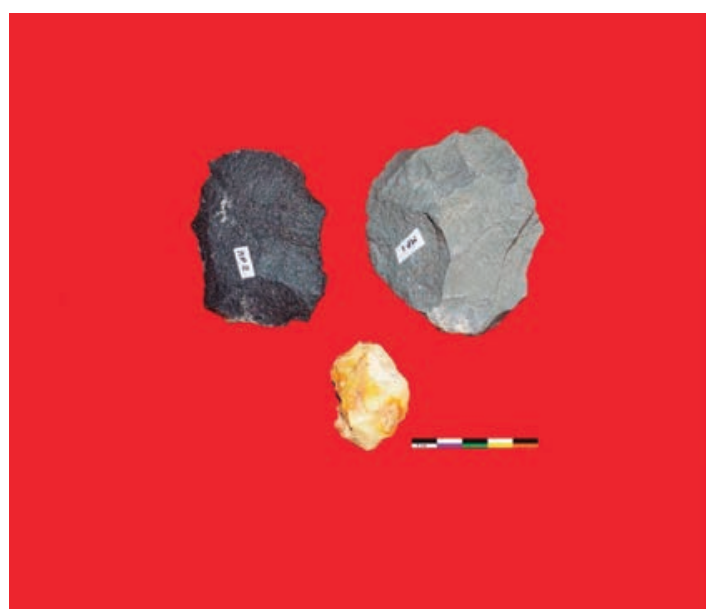

Figura 20: Vista de Núcleos, 2 en basalto y 1 en Chert.

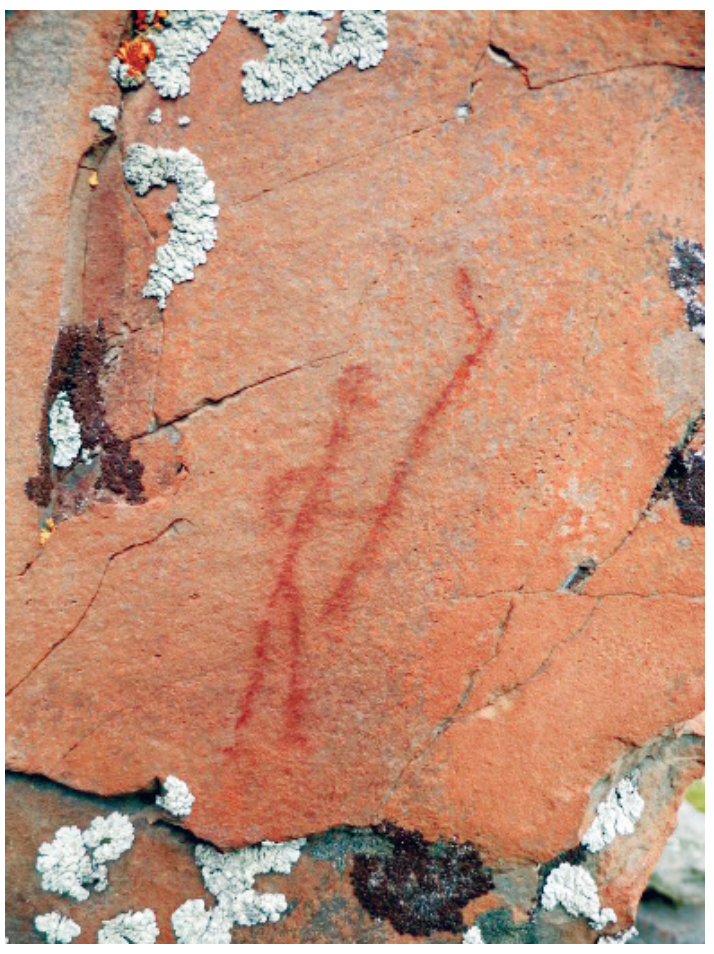

Figura 19: Representación en detalle de un personaje portando un arma en el brazo izquierdo.

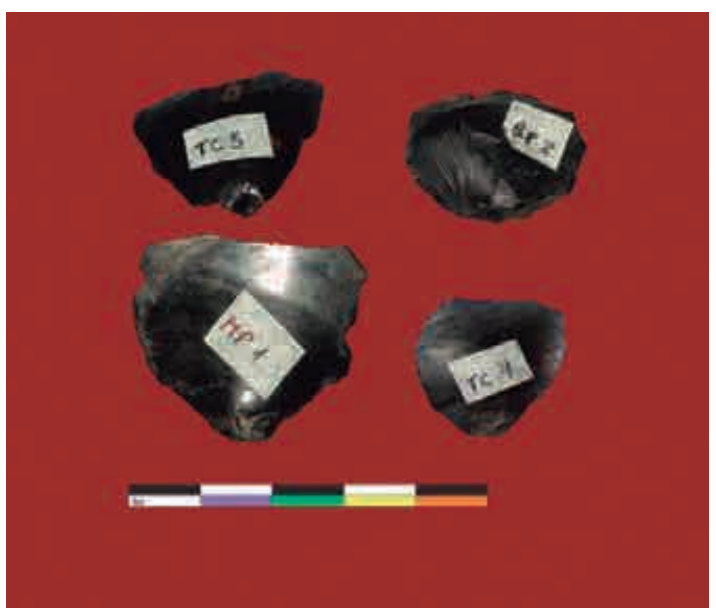

Figura 21: Vista de lascas sin modificación. 


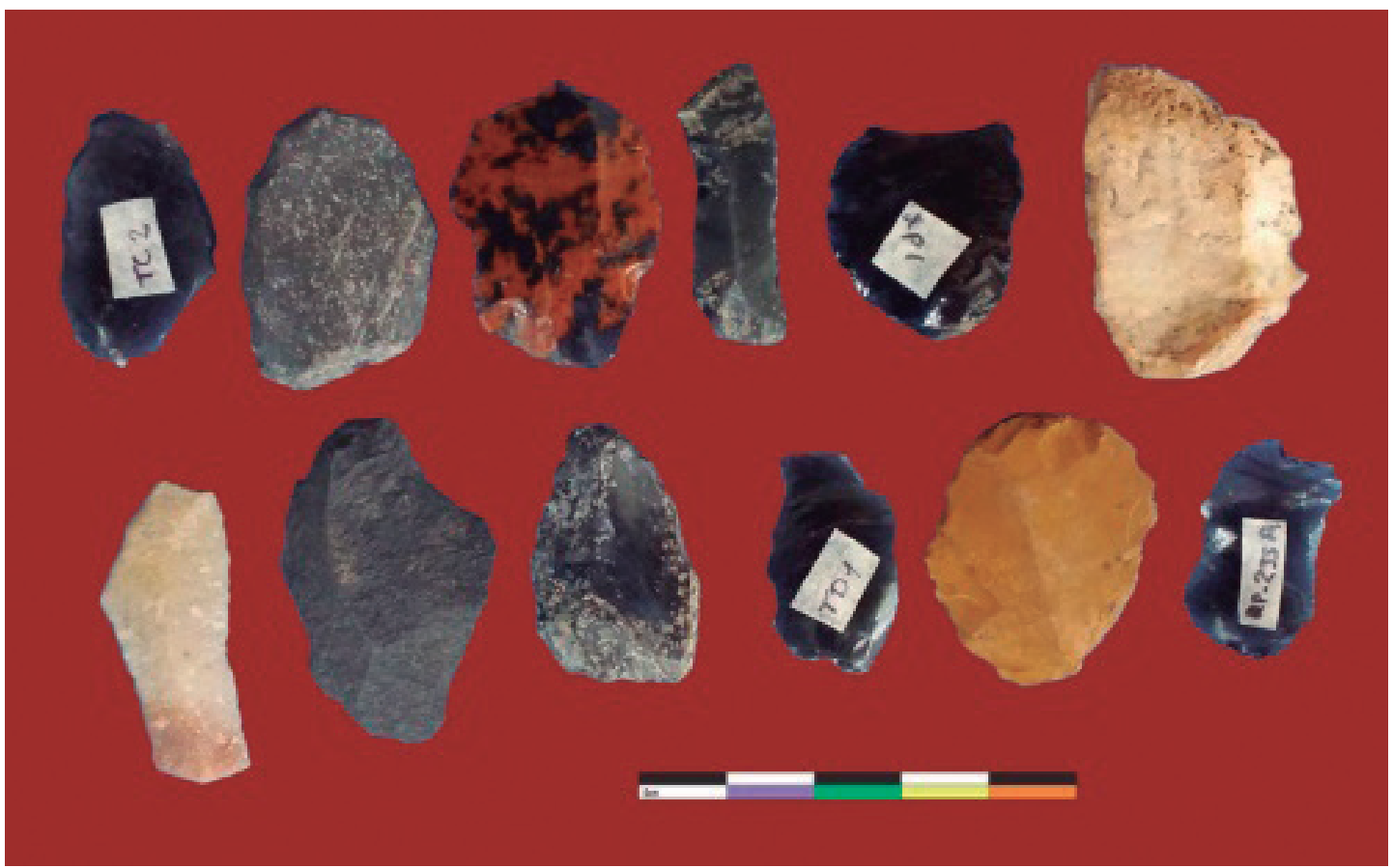

Figura 22: Vista de láminas sin modificación.

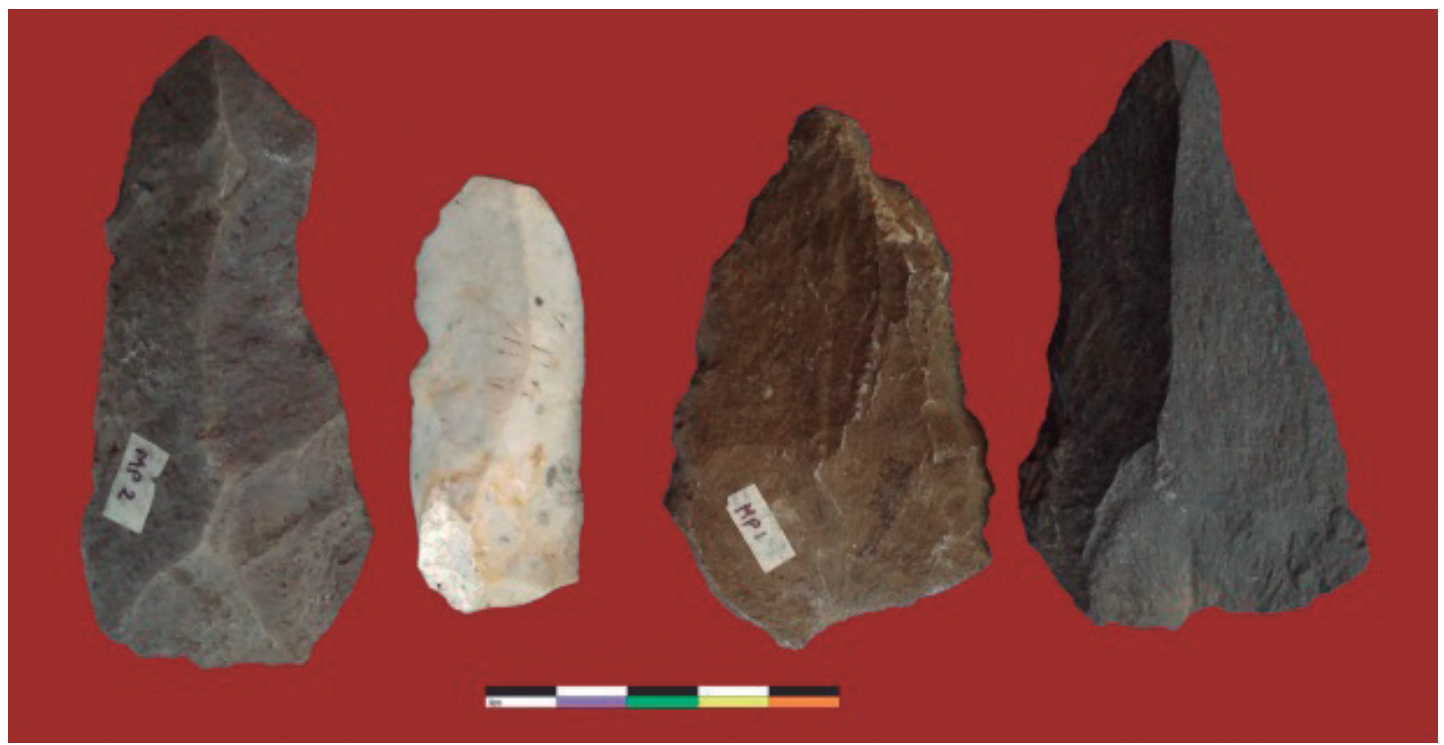

Figura 23: Vista de láminas sin modificación. 


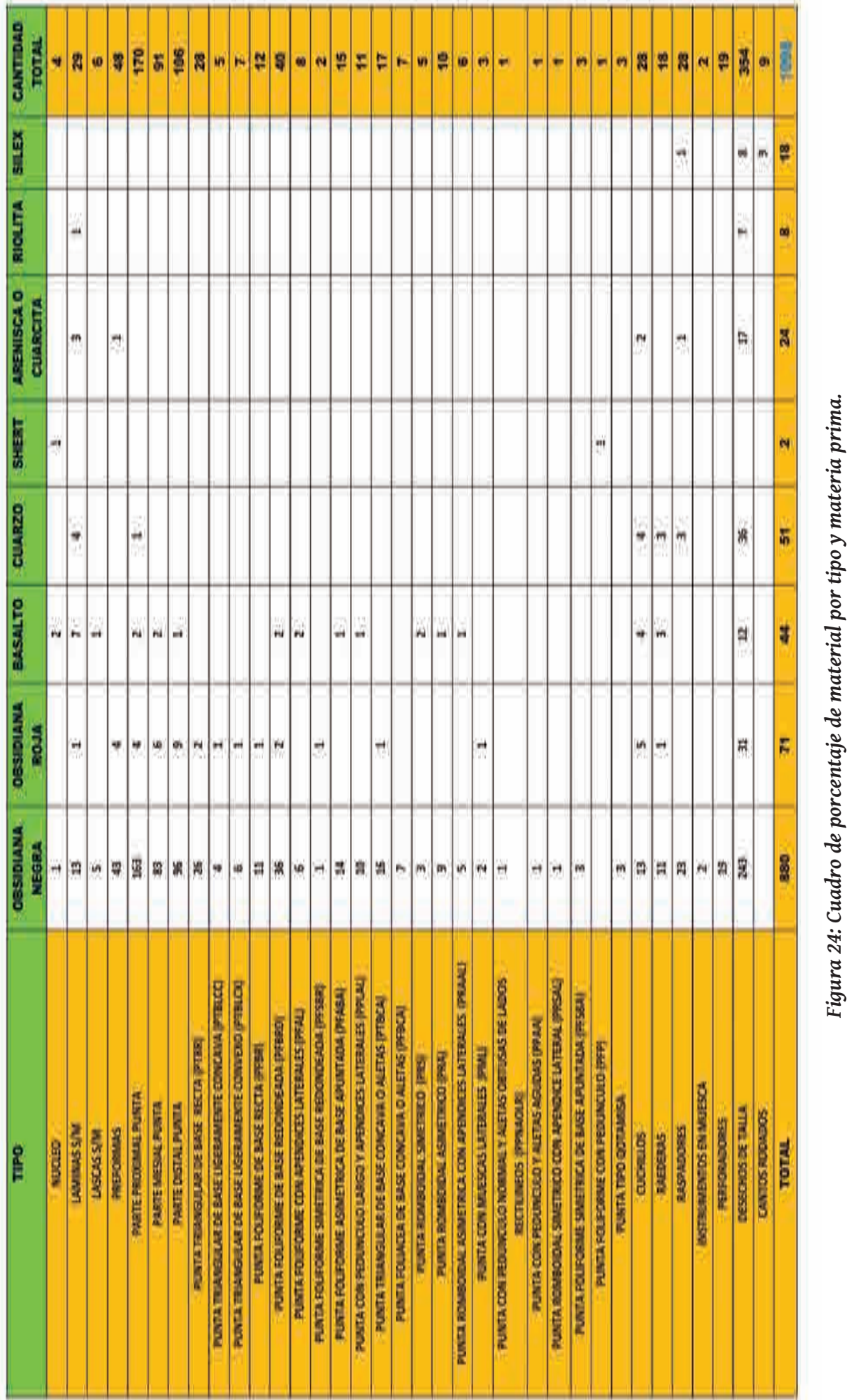


Punta Triangular de Base Recta (PTBR). Se trata de un tipo de punta de forma triangular y de base recta, el extremo penetrante es recto convergente. Se tiene en total 28 artefactos de este tipo, de los cuales 26 están elaborados de obsidiana de color negro y 2 están elaborados en obsidiana de color rojo. Las medidas que estas tienen varían de $1.8 \mathrm{~cm}$ a $4.6 \mathrm{~cm}$ de largo, de $1.3 \mathrm{~cm}$ a $2.2 \mathrm{~cm}$ de ancho y de $0.4 \mathrm{~cm}$ a $0.9 \mathrm{~cm}$ de espesor. Presentan retoques bifaciales generales, la mayoría de las piezas presentan una delineación de bordes convexo, la extensión de los retoques varían, pueden ser regulares, cubrientes o invasores. La inclinación del retoque es generalmente oblicuo, la forma de estos retoques también varían, pueden tener un retoque escamoso, paralelo o sub paralelo. (ver figura 25: A, B, C).

Punta Triangular de Base Ligeramente Convexo (PTBLCX). Es una punta de forma triangular, esta tiene una base que es ligeramente cóncava, el extremo penetrante es recto convergente. Se tiene en total 5 artefactos de este tipo, de los cuales 4 están elaborados en obsidiana de color negro y 1 en obsidiana de color rojo. Las medidas que estas tienen varían de $2.7 \mathrm{~cm}$ a $3.7 \mathrm{~cm}$ de largo, de $1.8 \mathrm{~cm}$ a $2.7 \mathrm{~cm}$ de ancho y de $0.4 \mathrm{~cm}$ a $0.6 \mathrm{~cm}$ de espesor. Presentan retoques bifaciales generales, la delineación de bordes es convexo y denticulado, la extensión de los retoques varían, pueden ser regulares, cubrientes o invasores. La inclinación del retoque es generalmente oblicuo, la forma de estos retoques varían, pueden tener un retoque escamoso, paralelo o subparalelo (ver figura 25: D, E).

Punta Triangular de Base Ligeramente Cóncava (PTBLCC). La morfología de estos artefactos es de forma triangular en el cual la forma de la base es ligeramente convexa. Se tiene en total 7 artefactos de este tipo, de los cuales 6 están elaborados en obsidiana de color negro y 1 en obsidiana de color rojo. Las medidas varían de $2 \mathrm{~cm}$ a $4.4 \mathrm{~cm}$ de largo, de $1.5 \mathrm{~cm}$ a $2.3 \mathrm{~cm}$ de ancho y de $0.4 \mathrm{~cm}$ a $0.6 \mathrm{~cm}$ de espesor. Presentan retoques bifaciales generales, la mayoría de las piezas presentan una delineación de bordes convexo, tambien presentan una delineación sinuosa y denticulado, la extensión de los retoques varían son: regulares, cubrientes o invasores. La inclinación del retoque es generalmente oblicuo, la forma de estos retoques también varían, presentan un retoque escamoso, paralelo o subparalelo (ver figura 25: $\mathrm{F}, \mathrm{G}$ ).

Punta Triangular de Base Cóncava o Aletas (PTBCA). Son artefactos de silueta en forma triangular que tiene una base cóncava y presentan aletas, los lados del cuerpo tienen una delineación rectilínea. Se tiene en total 17 artefactos de este tipo, de los cuales 16 están elaborados en obsidiana de color negro y 1 en obsidiana roja. Las medidas varían de $1.5 \mathrm{~cm}$ a $3.9 \mathrm{~cm}$ de largo, de $1.4 \mathrm{~cm}$ a $1.9 \mathrm{~cm}$ de ancho y de $0.4 \mathrm{~cm}$ a $0.6 \mathrm{~cm}$ de espesor. Presentan retoques bifaciales generales y la delineación de los bordes es convexo, la extensión de los retoques varían, son regulares, cubrientes o invasores. La inclinación del retoque es oblicuo, la forma de los retoques varían, presentan retoques escamoso, paralelo o subparalelo. (ver figura 25: $\mathrm{H}, \mathrm{I}, \mathrm{J}$ ).

Punta Foliforme de Base Recta (PFBR). Se trata de una punta de cuerpo foliáceo con un extremo apuntado y de base recta. Se tiene en total 12 artefactos de este tipo, de los cuales 11 están elaborados en obsidiana de color negro y 1 en obsidiana roja. Las medidas varían de $3.7 \mathrm{~cm}$ a $7.2 \mathrm{~cm}$ de largo, de $1.6 \mathrm{~cm}$ a $2.8 \mathrm{~cm}$ de ancho y de $0.4 \mathrm{~cm}$ a $0.9 \mathrm{~cm}$ de espesor. Presentan retoques bifaciales generales, y la delineación de los bordes es convexo, la extensión de los retoques varían, pueden ser regulares, cubrientes o invasores. La inclinación del retoque es generalmente oblicuo, la forma de estos retoques varían, pueden tener un retoque escamoso, paralelo o subparalelo (ver figura 25: K, L, M).

Punta Foliforme de Base Redondeada (PFBRD). Se tratan de puntas de cuerpo foliáceo, con un extremo apuntado y de base redondeada. Se tiene en total 40 artefactos de este tipo, de los cuales 36 están elaborados en obsidiana de color negro, 2 en obsidiana de color rojo y 2 en basalto. Las medidas varían de $5.8 \mathrm{~cm}$ a $2.7 \mathrm{~cm}$ de largo, de $1 \mathrm{~cm}$ a $3.5 \mathrm{~cm}$ de ancho y de $0.4 \mathrm{~cm}$ a $0.9 \mathrm{~cm}$ de espesor. Presentan 
retoques bifaciales generales, la mayoría de las piezas presentan una delineación de bordes convexo, la extensión de los retoques varían, regulares, cubrientes o invasores. La inclinación del retoque es generalmente oblicuo, la forma de estos retoques también varían, presentan un retoque escamoso, paralelo o subparalelo (ver figura 25: $\tilde{N}$ y figura 26: A, B ).

Punta Foliforme con Apéndices Laterales (PFAL). Se tratan de puntas de cuerpo foliáceo, estas presentan unos apéndices laterales pequeños. Se tiene en total 40 artefactos de este tipo, de los cuales 36 están elaborados en obsidiana de color negro, 2 en obsidiana de color rojo y 2 en basalto. Las medidas varían de $5.8 \mathrm{~cm}$ a $2.7 \mathrm{~cm}$ de largo, de $1 \mathrm{~cm}$ a $3.5 \mathrm{~cm}$ de ancho y de $0.4 \mathrm{~cm}$ a $0.9 \mathrm{~cm}$ de espesor. Presentan retoques bifaciales generales, la mayoría de las piezas presentan una delineación de bordes convexo, la extensión de los retoques varían, pueden ser regulares, cubrientes o invasores. La inclinación del retoque es generalmente oblicuo, la forma de estos retoques también varían, tienen retoque escamoso, paralelo o subparalelo (ver figura 26: C, D).

Punta Foliforme Simétrica de Base Redondeada (PFSBR). Son puntas de cuerpo foliáceo, de cuerpo simétrico y de base redondeada. Se tiene en total 40 artefactos de este tipo, de los cuales 36 están elaborados en obsidiana de color negro, 2 está elaborados en obsidiana de color rojo y 2 están elaborados en basalto. Las medidas varían de $5.8 \mathrm{~cm}$ a $2.7 \mathrm{~cm}$ de largo, de $1 \mathrm{~cm}$ a $3.5 \mathrm{~cm}$ de ancho y de $0.4 \mathrm{~cm}$ a $0.9 \mathrm{~cm}$ de espesor. Presentan retoques bifaciales generales, la mayoría de las piezas presentan una delineación de bordes convexo, la extensión de los retoques varían, pueden ser regulares, cubrientes o invasores. La inclinación del retoque es generalmente oblicuo, la forma de estos retoques también varían, retoque escamoso, paralelo o subparalelo (ver figura 26: E, F, G).

Punta Foliforme Asimétrica de Base Apuntada (PFABA). Se trata de un tipo de punta de cuerpo foliáceo con un extremo apuntado y de base apuntada, estos tipos presentan el cuerpo asimétrico. Se tiene en total 40 artefactos de este tipo, de los cuales 36 están elaborados en obsidiana de color negro, 2 en obsidiana roja y 2 en basalto. Las medidas varían de $5.8 \mathrm{~cm}$ a $2.7 \mathrm{~cm}$ de largo, de $1 \mathrm{~cm}$ a 3.5 $\mathrm{cm}$ de ancho y de $0.4 \mathrm{~cm}$ a $0.9 \mathrm{~cm}$ de espesor. Presentan retoques bifaciales generales, la mayoría de las piezas presentan una delineación de bordes convexo, la extensión de los retoques varían, pueden ser regulares, cubrientes o invasores. La inclinación del retoque es generalmente oblicuo, la forma de estos retoques también, presentan retoque escamoso, paralelo o subparalelo. (ver figura 26: $\mathrm{H}, \mathrm{I}$ ).

Punta Foliforme Simétrica de Base Apuntada (PFSBA). Se trata de una punta de cuerpo foliáceo con un extremo apuntado y de base recta, estos tipos presentan el cuerpo simétrico. Se tiene en total 3 artefactos de este tipo, todos están elaborados en obsidiana. Las medidas varían de $4.6 \mathrm{~cm}$ a $5.1 \mathrm{~cm}$ de largo, de $1.9 \mathrm{~cm}$ a $3.2 \mathrm{~cm}$ de ancho y de $0.8 \mathrm{~cm}$ a $0.9 \mathrm{~cm}$ de espesor. Presentan retoques bifaciales generales que se distribuyen por toda la pieza, la delineación de bordes es denticulado y convexo, la extensión de los retoques varían pueden ser cubrientes como también invasores, la inclinación del retoque es oblicuo, la forma de estos retoques son escamoso, paralelo o subparalelo (Ver Figura 26: J, K).

Punta Foliforme de Base Cóncava o Aletas (PFBCA). Se trata de una punta de cuerpo foliáceo con un extremo apuntado y de base cóncava conocido también como aletas. Se tiene 6 artefactos correspondientes a este tipo, están elaborados en obsidiana. Las medidas varían de $1.4 \mathrm{~cm}$ a $2.1 \mathrm{~cm}$ de largo, de $1.9 \mathrm{~cm}$ a $2.6 \mathrm{~cm}$ de ancho y de $0.5 \mathrm{~cm}$ a $0.6 \mathrm{~cm}$ de espesor. Presentan retoques bifaciales generales que se distribuyen por toda la pieza, la delineación de bordes es denticulado y convexo, la extensión de los retoques varían son cubrientes e invasores, la inclinación del retoque es oblicuo, la forma de estos retoques son retoque escamoso, paralelo o subparalelo (ver figura 26: L, M).

Punta Foliforme con Pedúnculo (PFP). Se trata de una punta de cuerpo foliáceo con un extremo apuntado, estos artefactos presentan un pedúnculo. Se cuenta con 2 artefactos elaborados en obsidia- 

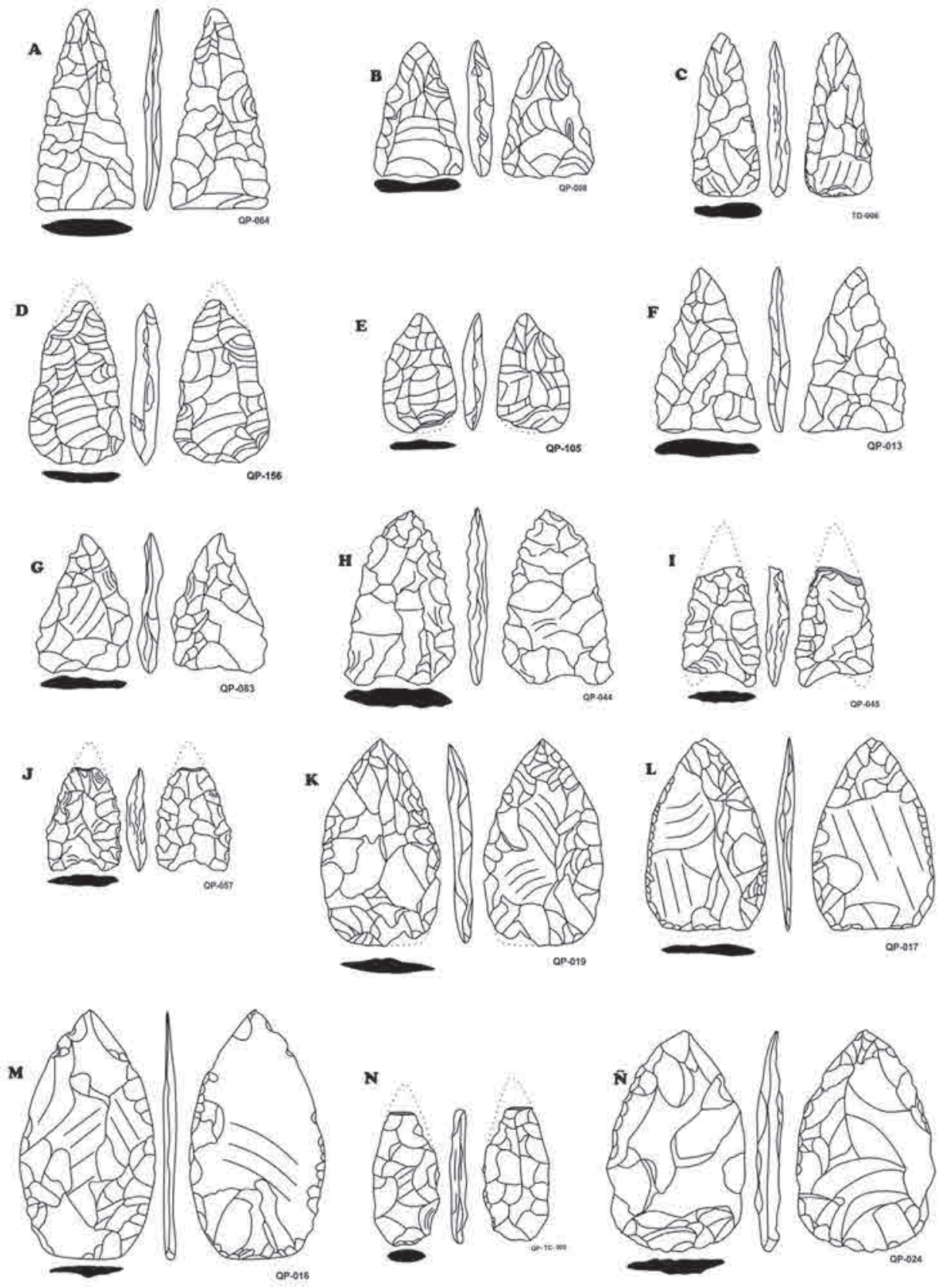

Figura 25: A, B, C: Punta Triangular de base recta; D, E: Punta Triangular de base ligeramente convexo; F, G: Punta triangular de base ligeramente cóncava; H, I, J: Punta triangular de base cóncava o aletas; K, L, M: Punta Foliforme de Base Recta; N, Ñ: Punta Foliforme de Base Redondeada. 

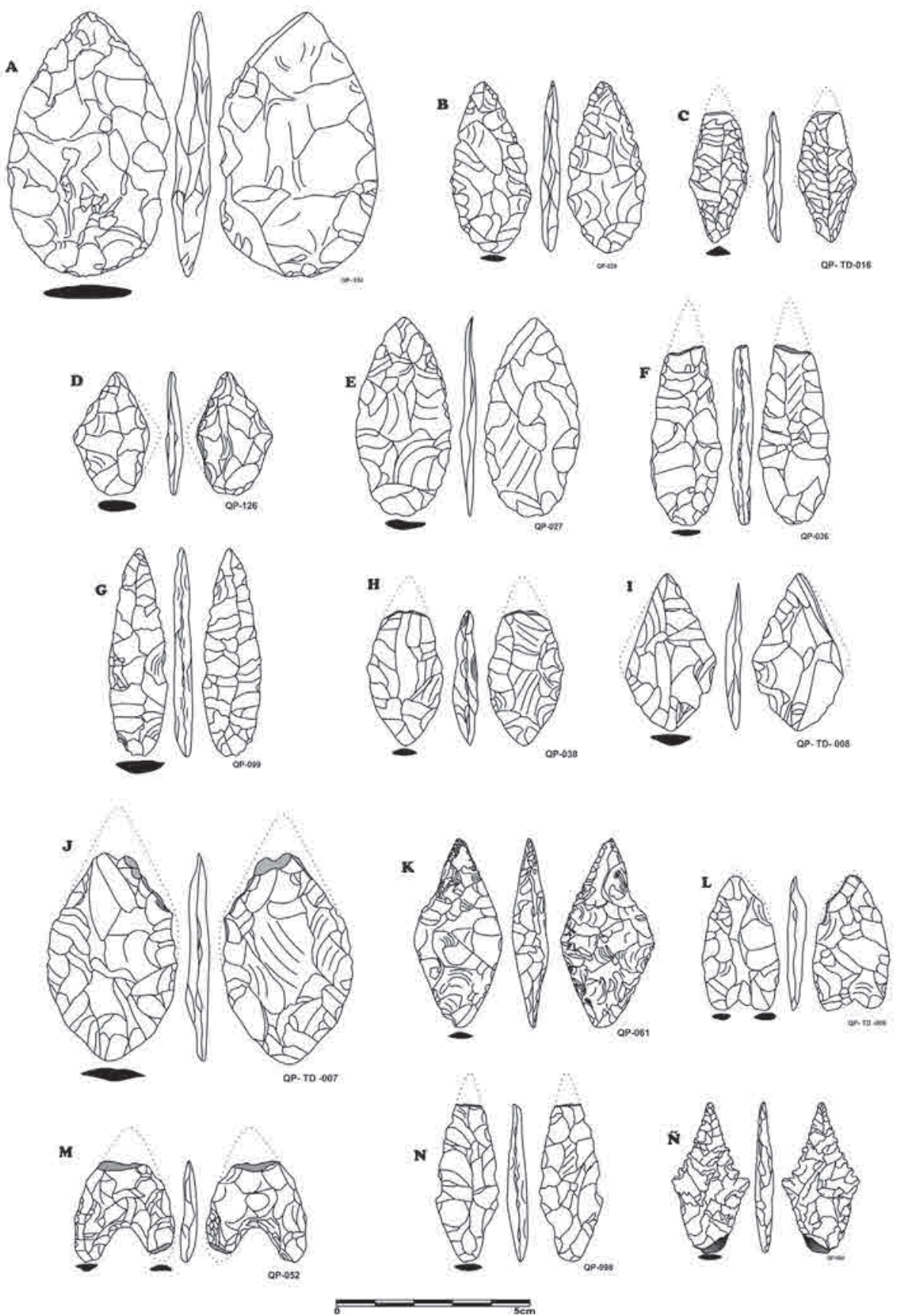

Figura 26: A, B: Punta Foliforme de Base Redondeada; C, D: Punta Foliforme con apéndices laterales; E, F, G: Punta Foliforme Simétrica de Base Redondeada; H, I: Punta Foliforme Asimétrica de Base Apuntada; J, K: Punta Foliforme Simétrico de Base Apuntada; L, M: Punta foliácea de base cóncava o aletas; N: Punta Foliforme con Pedúnculo, Ñ: Punta Romboidal Simétrico con apéndice lateral. 
na. Las medidas varían de $3.3 \mathrm{~cm}$ a $4 \mathrm{~cm}$ de largo, de $1.1 \mathrm{~cm}$ a $1.5 \mathrm{~cm}$ de ancho y de $0.5 \mathrm{~cm}$ a $0.6 \mathrm{~cm}$ de espesor. Presentan retoques bifaciales generales que se distribuyen por toda la pieza, la delineación de bordes es pedúnculo, la extensión de los retoques son cubrientes, la inclinación del retoque es oblicuo, la forma de los retoques es escamoso y paralelo (ver figura 26: N).

Punta Romboidal Simétrico con Apéndice Lateral (PRSAL). Se trata de una punta de cuerpo romboidal con un extremo apuntado, estos artefactos presentan apéndices en ambos lados, presentan un cuerpo simétrico. Se cuenta con 1 artefacto correspondiente a este tipo, está elaborado en obsidiana. El largo del artefacto es de $3.1 \mathrm{~cm}$ de largo, $1.9 \mathrm{~cm}$ de ancho y $0.6 \mathrm{~cm}$ de espesor. Presenta un retoque bifacial general que se distribuye por toda la pieza, la delineación del borde es convexo, la extensión del retoque es cubriente, la inclinación del retoque es oblicuo, la forma del retoque es paralelo (ver figura 26: $\tilde{N})$.

Punta Romboidal Asimétrica con Apéndices laterales (PRAAL). Se trata de una punta de cuerpo romboidal con un extremo apuntado, estos artefactos presentan apéndices en ambos lados. Presentan un cuerpo asimétrico. Se cuenta con 6 artefactos de este tipo, 5 están elaborados en obsidiana y 1 en basalto. Las medidas varían de $2.3 \mathrm{~cm}$ a $3.3 \mathrm{~cm}$ de largo, $1.4 \mathrm{~cm}$ a $1.9 \mathrm{~cm}$ de ancho y de $0.4 \mathrm{~cm}$ a $0.9 \mathrm{~cm}$ de espesor. Presentan retoques bifaciales generales que se distribuyen por toda la pieza, la delineación de bordes es convexo y denticulado, la extensión de los retoques son cubrientes e invasores, la inclinación del retoque es oblicuo, la forma de estos retoques varían: pueden ser escamoso, paralelo y subparalelo (ver figura 27: A, B).

Punta Romboidal Simétrico (PRS). Se trata de un tipo de punta de cuerpo Romboidal con un extremo apuntado. Presentan un cuerpo simétrico. Se cuenta con 4 artefactos de este tipo, 3 están elaborados en obsidiana y 1 en basalto. Las medidas varían de $2.6 \mathrm{~cm}$ a $2.9 \mathrm{~cm}$ de largo, de $1.4 \mathrm{~cm}$ a $2.3 \mathrm{~cm}$ de ancho y de $0.5 \mathrm{~cm}$ a $0.6 \mathrm{~cm}$ de espesor. Presentan retoques bifaciales generales que se distribuyen por toda la pieza, la delineación de bordes es convexo, la extensión de los retoques son cubrientes, la inclinación del retoque es oblicuo, la forma de los retoques es escamoso (ver Figura 27: C, D).

Punta Romboidal Asimétrico (PRA). Se trata de un tipo de punta de cuerpo romboidal con un extremo apuntado. Presentan un cuerpo asimétrico. Se cuenta con 10 artefactos de este tipo, 9 están elaborados en obsidiana y 1 en basalto. Las medidas varían de $2 \mathrm{~cm}$ a $5.7 \mathrm{~cm}$ de largo, $1.3 \mathrm{~cm}$ a $2.5 \mathrm{~cm}$ de ancho y de $0.5 \mathrm{~cm}$ a $0.6 \mathrm{~cm}$ de espesor. Presentan retoques bifaciales generales que se distribuyen por toda la pieza, la delineación de bordes es convexo, la extensión de los retoques son cubrientes e invasores, la inclinación del retoque es oblicuo, la forma de los retoques es escamoso, paralelo y subaparalelo (ver figura 27: E, F, G).

Punta con Muescas Laterales (PML). Se trata de un tipo de punta de cuerpo alargado y presentan muescas en ambos lados del artefacto. Se cuenta con 3 artefactos elaboradas en obsidiana. Las medidas varían de $2.7 \mathrm{~cm}$ a $4.9 \mathrm{~cm}$ de largo, de $1.5 \mathrm{~cm}$ a $1.8 \mathrm{~cm}$ de ancho y de $0.3 \mathrm{~cm}$ a $0.6 \mathrm{~cm}$ de espesor. Presentan retoques bifaciales generales que se distribuyen por toda la pieza, la delineación de bordes es convexo y denticulado, la extensión de los retoques son cubrientes y regulares, la inclinación del retoque es oblicuo, la forma de estos retoques es escamoso y paralelo (ver figura 27: H, I).

Punta con Pedúnculo Normal y Aletas Obtusas de Lados Rectilíneos (PPNAOLR). Se trata de una punta de cuerpo alargado y extremo penetrante con pedúnculo, aletas obtusas y que ambos lados de las paredes son rectas. Se cuenta con 1 artefacto de este tipo, está elaborado en obsidiana. El largo del artefacto es de $3.2 \mathrm{~cm}$ de largo, $1.7 \mathrm{~cm}$ de ancho y $0.5 \mathrm{~cm}$ de espesor. Presenta un retoque bifacial general que se distribuye por toda la pieza, la delineación del borde es pedúnculo, la extensión del retoque es cubriente, la inclinación del retoque es oblicuo, la forma del retoque es paralelo (ver Figura 27: J). 

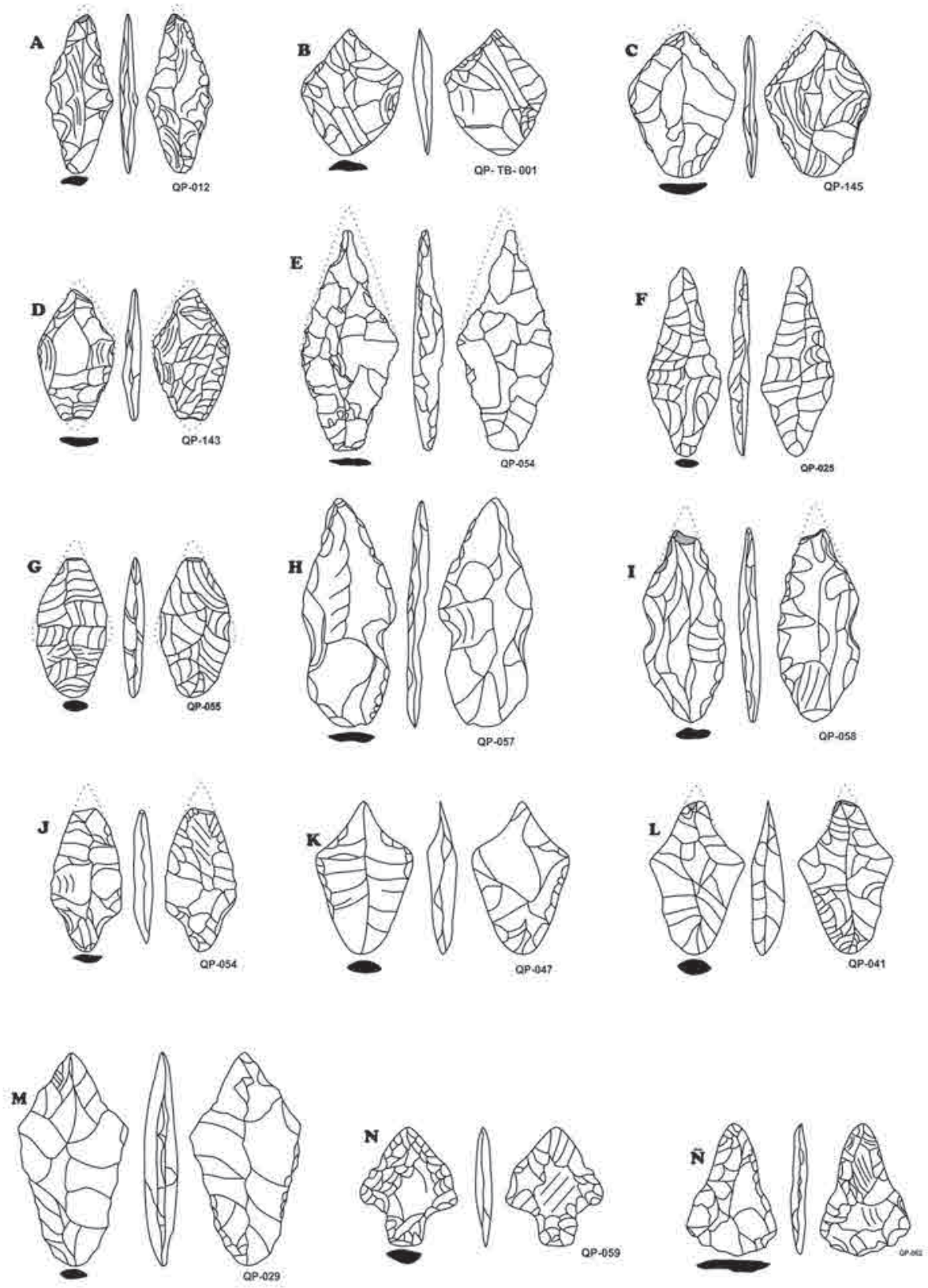

27: A, B: Punta Romboidal Asimétrica con Apéndices Laterales; C, D: Punta romboidal Simétrico; E, F, G: Punta romboidal asimétrica; H, I: Punta con muescas laterales; J: Punta con pedúnculo normal y aletas obtusas de lados rectilíneos; K, L, M: Punta con pedúnculo largo y apéndices laterales; N: Punta con pedúnculo y aletas agudas; N: Punta Tipo Qotamisa. 
Punta con Pedúnculo Largo y Apéndices Laterales (PPLAL). Se trata de una punta con un extremo penetrante, presentan un pedúnculo largo y tiene apéndices en ambos lados de sus paredes. Se cuenta con 10 artefactos correspondientes a este tipo, elaborados en obsidiana. Las medidas varían de $2.2 \mathrm{~cm}$ a $4.0 \mathrm{~cm}$ de largo, $1.5 \mathrm{~cm}$ a $1.9 \mathrm{~cm}$ de ancho y de $0.5 \mathrm{~cm}$ a $0.8 \mathrm{~cm}$ de espesor. Presentan retoques bifaciales generales que se distribuyen por toda la pieza, la delineación de bordes es convexo y denticulado, la extensión de los retoques son cubrientes, la inclinación del retoque es oblicuo, la forma de estos retoques es escamoso, paralelo y subparalelo (ver figura 27: K, L, M).

Punta con Pedúnculo y Aletas Agudas (PPAA). Se trata de una punta de cuerpo alargado con un extremo apuntado, tienen aletas y presentan un pedúnculo. Se cuenta con 1 artefacto correspondiente a este tipo, está elaborado en obsidiana. El largo del artefacto es de $2.5 \mathrm{~cm}$ de largo, $2.1 \mathrm{~cm}$ de ancho y $0.4 \mathrm{~cm}$ de espesor. Presenta un retoque bifacial general que se distribuye por toda la pieza, la delineación del borde es pedúnculo, la extensión del retoque es regular, la inclinación del retoque es oblicuo, la forma del retoque es paralelo. Está elaborado con la técnica de la presión y como soporte se tiene una lámina (ver figura 27: N).

Punta Qotamisa (PTQ). Se trata de una punta con un extremo penetrante, presentan un pedúnculo muy corto que forman una base cóncava. Se cuenta con 03 artefactos correspondientes a este tipo, elaborados en obsidiana. Las medidas varían de $1.3 \mathrm{~cm}$ a $2.8 \mathrm{~cm}$ de largo, de $1.1 \mathrm{~cm}$ a $1.8 \mathrm{~cm}$ de ancho y de $0.4 \mathrm{~cm}$ a $0.7 \mathrm{~cm}$ de espesor. Presentan retoques bifaciales generales que se distribuyen por toda la pieza, la delineación de bordes es convexo y sinuoso, la extensión de los retoques son cubrientes, la inclinación del retoque es oblicuo, la forma de estos retoques es escamoso y subparalelo (ver figura 27: $\tilde{\mathrm{N}})$.

Todos estos artefactos presentan los retoques hechos con la técnica de presión y como soporte tienen una lámina.

FRAGMENTOS DE PUNTAS. Dentro de este grupo se tiene a los fragmentos de punta recolectadas del sitio de Qotamisa Pampa, del total de estos fragmentos, 170 corresponden a la parte proximal, de las cuales un total de 163 están elaborados en obsidiana de color negro, 4 en obsidiana de color rojo, 2 en basalto y 1 en cuarzo. Un total de 91 fragmentos corresponden a la parte mesial de una punta, 83 están elaborados en obsidiana de color negro, 6 en obsidiana roja y 2 en basalto. Por último se tiene la parte distal con un total de 108 fragmentos, 96 elaborados en obsidiana de color negro, 9 en obsidiana roja y 1 en basalto (ver figura 28 a figura 33).

PREFORMAS DE PUNTA. Las preformas son aquellas piezas, que son el resultado de una preparación muy cuidada, es una forma aun imperfecta. Las preformas no son útiles funcionales, pero si son piezas retocadas (Juan 2008: 153). Para Qotamisa Pampa se tiene en total 48 preformas de Punta de las cuales 43 son de obsidiana negra, 4 en obsidiana roja y 1 en cuarcita (ver figura 34 y figura 35).

RAEDERA. Este instrumento está elaborado mediante retoques continuos y plano en uno o en más bordes. Se trata de un "instrumento con astillamiento continuo en un borde recto o ligeramente curvo, de frente de uso amplio. El ángulo de borde activo es agudo oblicuo, con algunas excepciones” (Lavallée 1970: 19). También las raederas "son laminas o lascas que muestran, en una o dos extremidades un retoque continuo no abrupto (simple) que determina un frente más o menos redondeado o parabólico, rara vez rectilíneo aún más rara vez cóncavo" (Merino 1994: 67). 


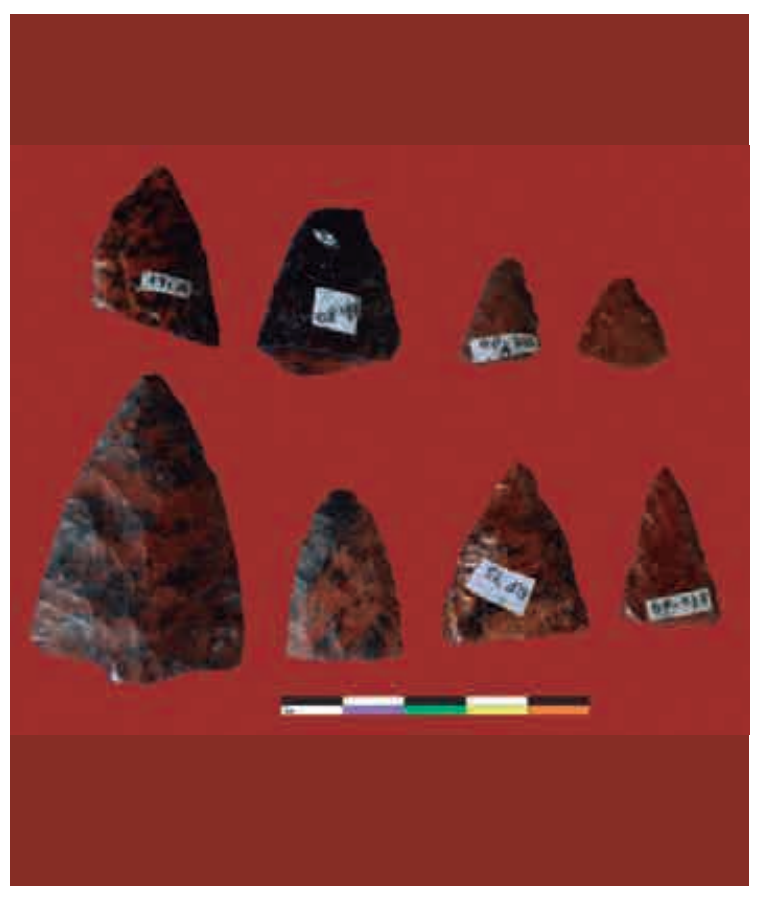

Figura 28: Fragmentos de punta, parte distal.

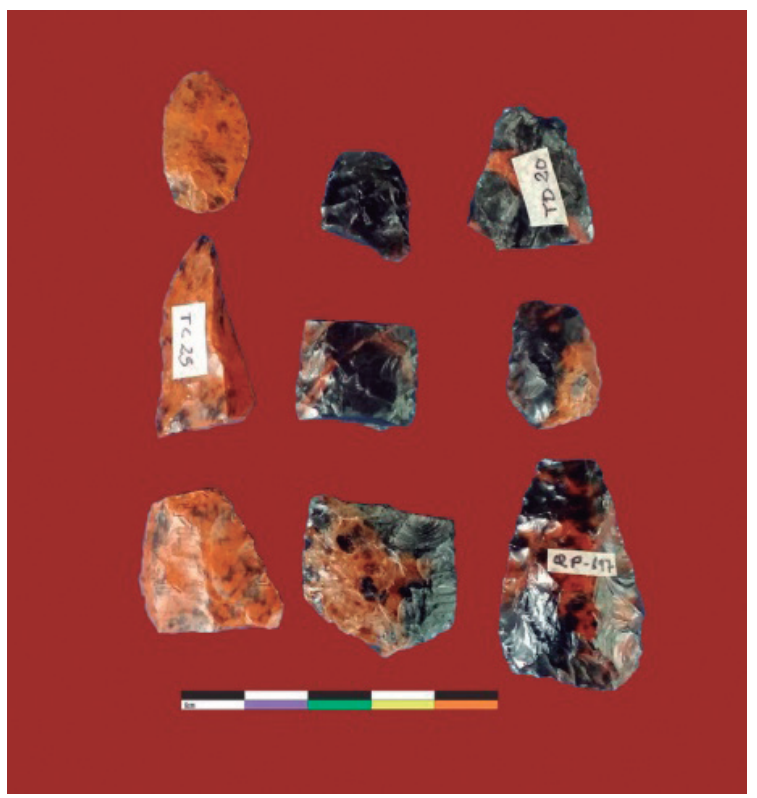

Figura 30: Fragmentos de punta, parte mesial.

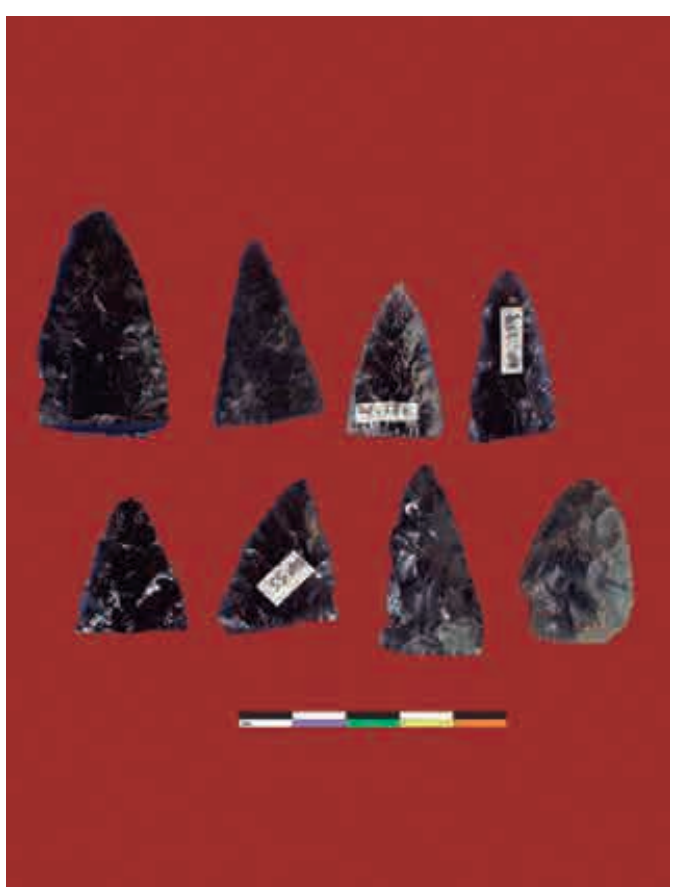

Figura 29: Fragmentos de punta, parte distal.

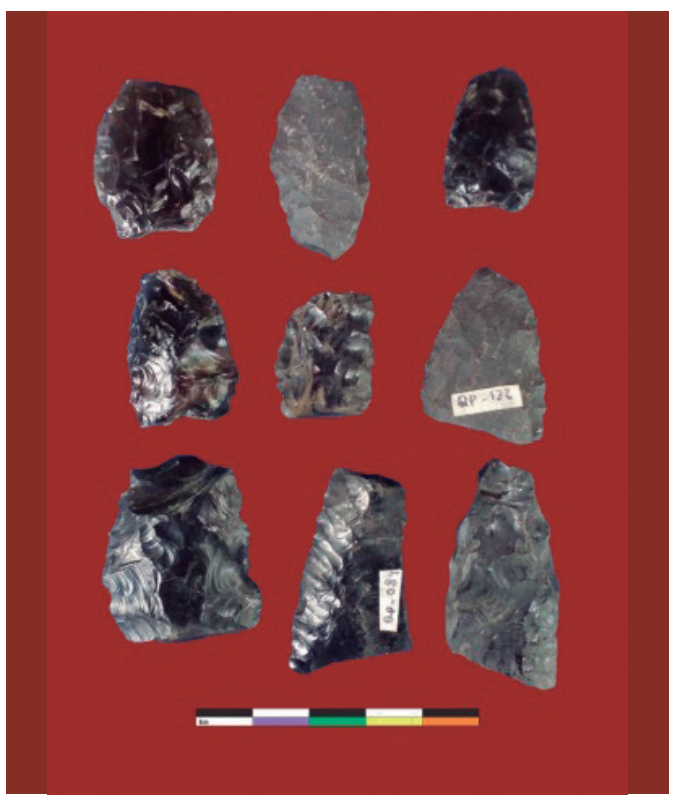

Figura 31: Fragmentos de punta, parte mesial. 


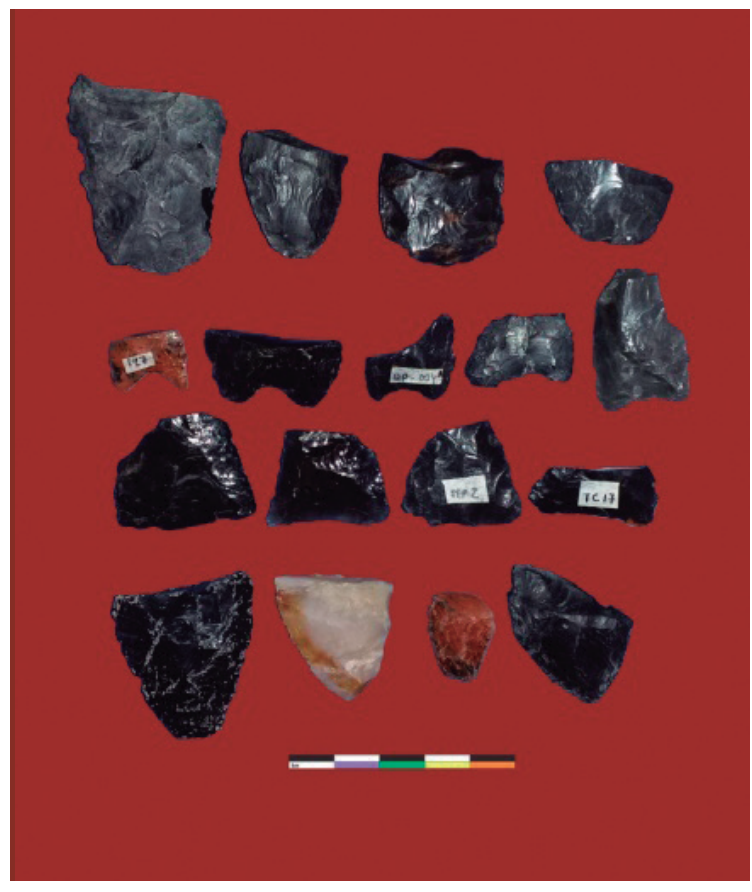

Figura 32: Fragmentos de punta, parte proximal.

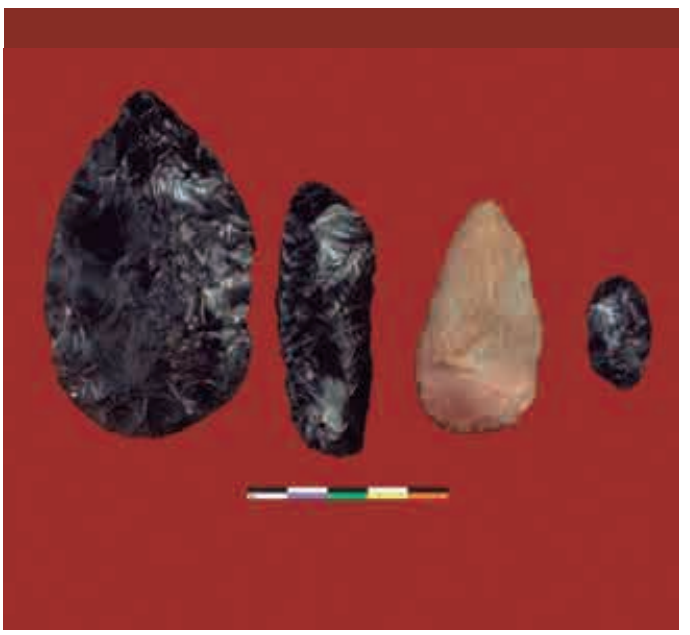

Figura 34: Preformas de Punta en Obsidiana y Basalto

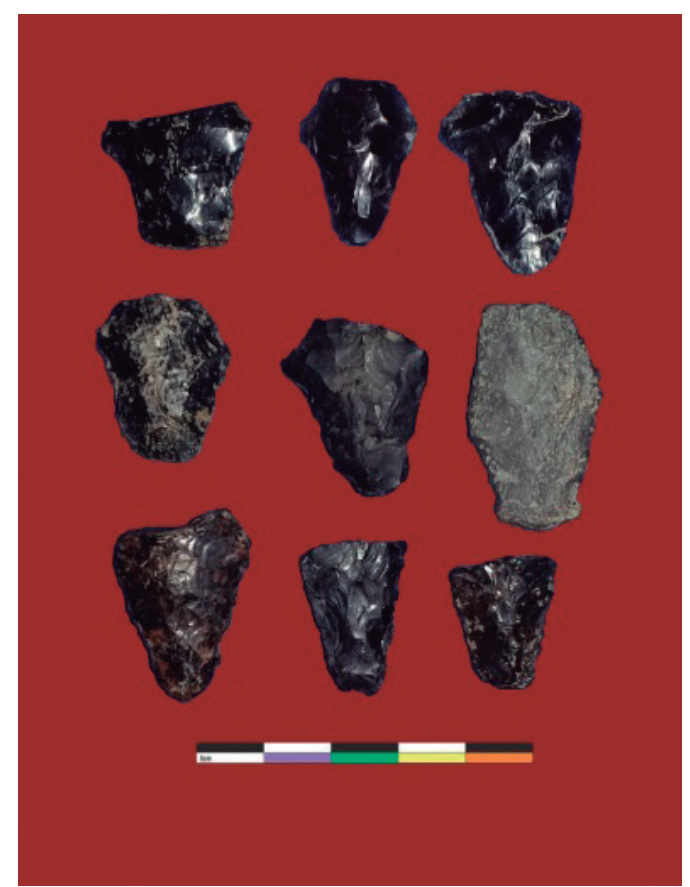

Figura 33: Fragmentos de punta, parte proximal. Tipos de Pedúnculos.

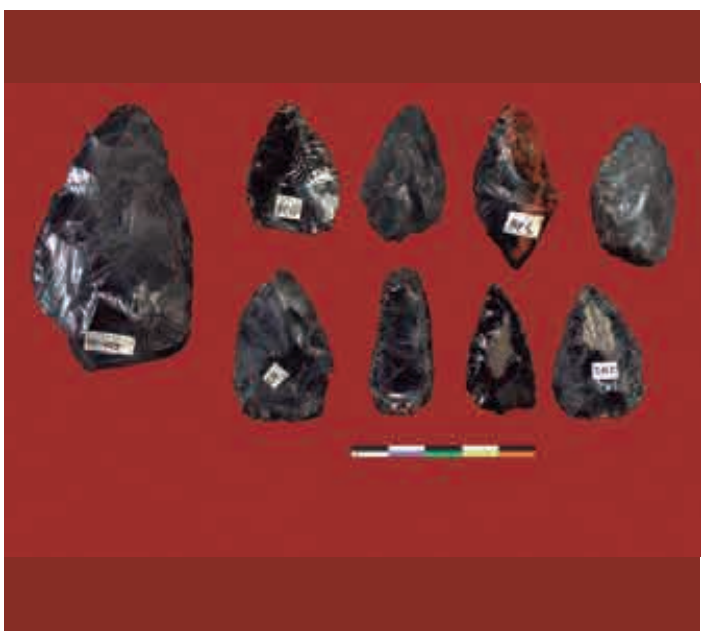

Figura 35: Preformas de Punta en Obsidiana y Basalto. 
Estos artefactos son usados bifacialmente, pudo haberse empleado para raspar y cortar las pieles y los pelos, también pudo usarse para ablandar vegetales, como también para raspar madera o hueso. Se tiene en total 18 artefactos de raedera, de los cuales 11 están elaborados en obsidiana de color negro, 1 en obsidiana de color rojo, 3 en basalto y 3 en cuarzo. Estos artefactos fueron definidos en función de los ángulos de borde activo (usualmente inferiores a los $70^{\circ}$ ).

\section{Tipos de Raederas}

Raedera Monolateral. Se tratan de artefactos que tienen retoque funcional en sólo uno de sus lados. Se cuenta en total con 9 artefactos de este tipo, están elaborados en obsidiana (6) y basalto (3), el promedio de ángulos de borde activo es de $35^{\circ}$. El borde activo está dado por una serie de golpes recurrentes, los lados muestran poco trabajo, aunque son resaltantes las extracciones y retoque en el borde derecho. Las medidas de estos artefactos varían de $3.0 \mathrm{~cm}$ a $6.3 \mathrm{~cm}$ de largo, de $2.0 \mathrm{~cm}$ a $3.7 \mathrm{~cm}$ de ancho y de $0.6 \mathrm{~cm}$ a $1.2 \mathrm{~cm}$ de espesor (ver figura 36 ).

Raedera- Cuchillo. Se tratan de artefactos de doble funcionalidad, también se puede denominar como artefactos compuestos que cumple funciones predominantes la de raer y la de cortar. Se tiene en total 5 artefactos de este tipo, están elaborados en cuarzo (3) y en obsidiana (2), el promedio de ángulos del borde activo es $30^{\circ}$, presenta retoques continuos, paralelos y subparalelos. Las medidas varían de $3.9 \mathrm{~cm}$ a $5.8 \mathrm{~cm}$ de largo, de $2.6 \mathrm{~cm}$ a $3.8 \mathrm{~cm}$ de ancho y de $0.7 \mathrm{~cm}$ a $1.0 \mathrm{~cm}$ de espesor (ver figura 37).

Raedera Bilateral. Se tratan de artefactos en la cual el trabajo se ha efectuado en ambos lados del artefacto y el retoque puede ser monofacial o bifacial. Se tiene en total 4 artefactos de este tipo, están elaborados en obsidiana, el promedio de ángulos del borde activo es $30^{\circ}$, presenta retoques continuos, paralelos y subparalelos. Las medidas varían de $3.2 \mathrm{~cm}$ a $4.3 \mathrm{~cm}$ de largo, de $2.1 \mathrm{~cm}$ a $2.5 \mathrm{~cm}$ de ancho y de $0.5 \mathrm{~cm}$ a $1.4 \mathrm{~cm}$ de espesor (ver figura 38 ).

CUCHILLOS. Los cuchillos son artefactos que tienen un borde cortante están elaboradas ya sean en lascas o en láminas: "Son útiles sobre lasca o lamina uno de cuyos bordes está formado por un corte bruto, no retocado, pero que puede mostrar huellas de utilización, y cuyo otro borde es la corteza del núcleo, o un retoque simple o abrupto según los casos" (Merino 1994: 67).

La posible funcionalidad de estos artefactos es la de cortar. Estos pueden presentar retoque bifacial y se ha podido usar con mango o sin ella. Se tiene en total 25 artefactos de los cuales 12 están elaborados en obsidiana de color negro, 3 en obsidiana de color rojo, 4 en basalto, 4 en cuarzo y 2 en arenisca. Las medidas varían desde $2.8 \mathrm{~cm}$ a $9.6 \mathrm{~cm}$ de largo, de $1.2 \mathrm{~cm}$ a $3.6 \mathrm{~cm}$ de ancho y de $0.4 \mathrm{~cm}$ a $1.4 \mathrm{~cm}$ de espesor.

Tipos de Cuchillos

Cuchillo con Filo en Estado Natural. Son artefactos que no presentan retoques, pero si presentan huellas de astillamiento bifacial continuo y corto esto indica que han sido usados como un utensilio.

Se cuenta en total con 14 artefactos, están elaborados en obsidiana (11), cuarzo (2) y basalto (1), los lados son rectos y cóncavos, el promedio de ángulos de borde activo es de $15^{\circ}$ a $25^{\circ}$. Presentan retoques en ambos lados, generalmente en el borde. La mayoría de estos tienen de soporte una lámina. Las medidas varían de $4.5 \mathrm{~cm}$ a $2.8 \mathrm{~cm}$ de largo, de $0.7 \mathrm{~cm}$ a $2.2 \mathrm{~cm}$ de ancho y de $0.3 \mathrm{~cm}$ a $0.9 \mathrm{~cm}$ de espesor (ver figura 39).

Cuchillo Alargado. Se tratan de cuchillos alargados de lados convexos. Se cuenta en total con 10 artefactos de este tipo, están elaborados en cuarzo (2), arenisca (2), obsidiana (3) y basalto (3); el 


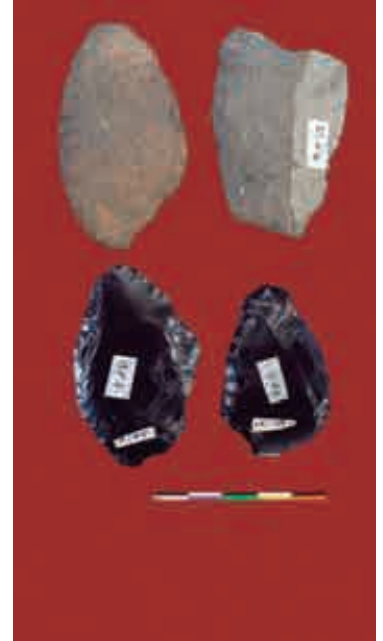

Figura 36: Raedera monolateral elaborado en Obsidiana y Basalto.

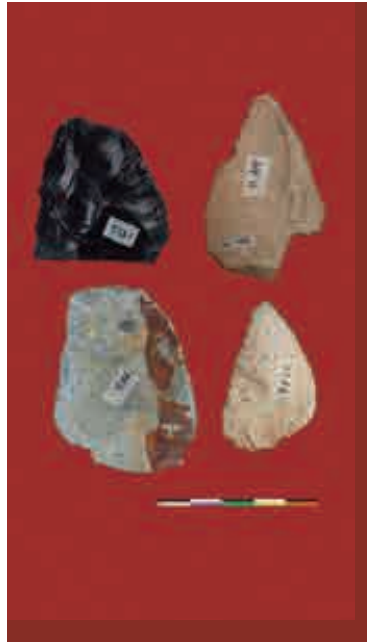

Figura 37: Raederascuchillo elaborado en Obsidiana y Cuarzo.

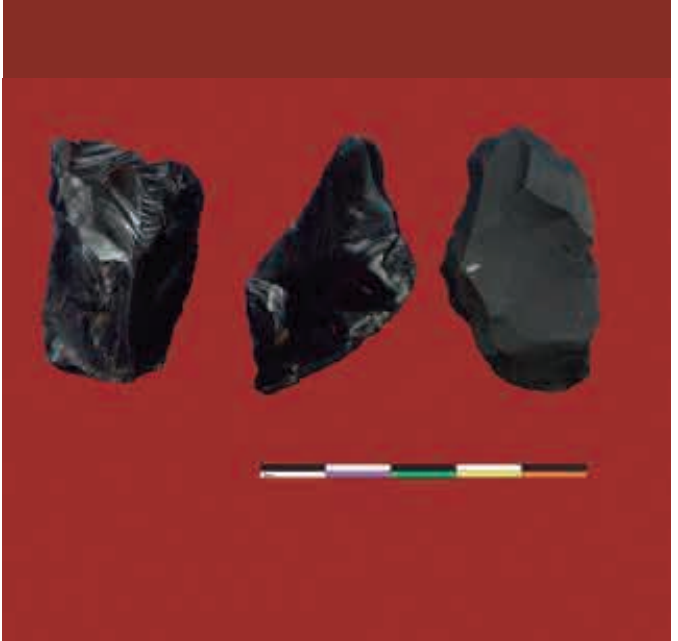

Figura 38: Raederas Bilateral elaborado en Obsidiana y Basalto.

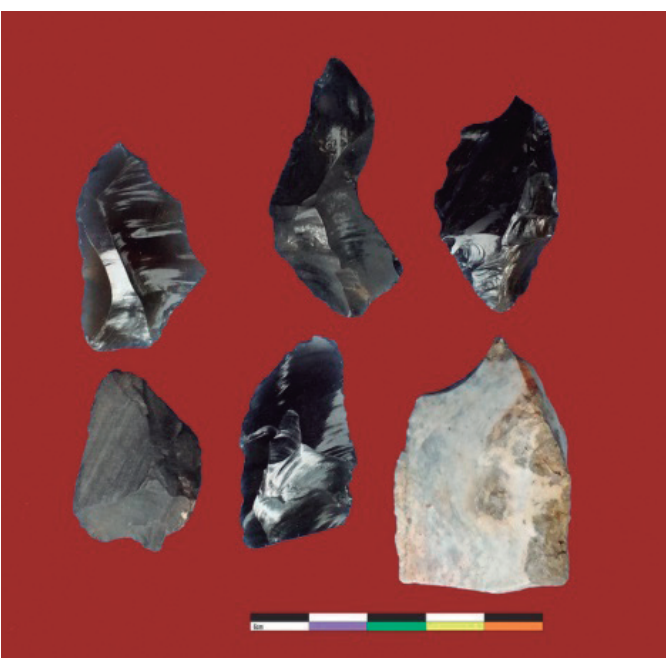

Figura 39: Cuchillo con filo en estado natural.

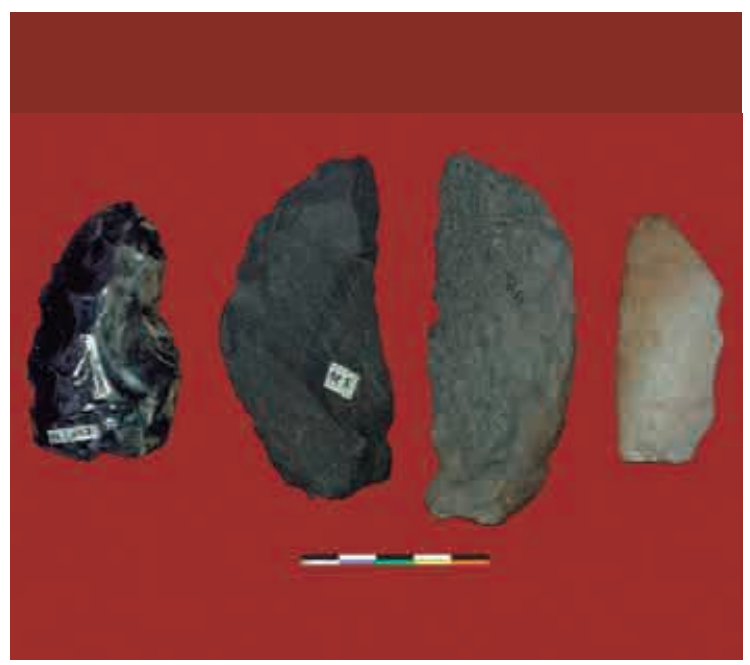

Figura 40: Cuchillos alargados.

promedio de ángulos de borde activo es de $10^{\circ}$ a $40^{\circ}$. Presentan retoques. Todas las piezas fueron retocadas por percusión blanda, el tipo de soporte es el bloque, algunos de estos tienen de soporte una lámina. Las medidas varían de $6.2 \mathrm{~cm}$ a $2 \mathrm{~cm}$ de largo, de $4.4 \mathrm{~cm}$ a $1.9 \mathrm{~cm}$ de ancho y de $0.5 \mathrm{~cm}$ a $1.1 \mathrm{~cm}$ de espesor (ver figura 40).

Cuchillo Sobre Lasca. Se tratan de cuchillos elaborados sobre una lasca, ha sido retocado tan sólo los bordes con retoque marginal doble, sobre la cual se observa claramente el bulbo y el plano de percusión. Se cuenta en total con 1 artefacto de este tipo elaborado en basalto, el promedio de ángulos 
de borde activo es de $25^{\circ}$ a $30^{\circ}$. Presentan retoques bifaciales. Esta pieza fue retocada por percusión blanda, el tipo de soporte es la lasca, algunos de estos tienen de soporte una lámina. Las medidas de este artefacto son de $4.2 \mathrm{~cm}$ de largo, $2.9 \mathrm{~cm}$ de ancho y $1.1 \mathrm{~cm}$ de espesor.

RASPADORES. Es un artefacto en donde la superficie ventral es plana y generalmente tiene un dorso alto sin rebajar que sirve para poder manipular el artefacto. Se trata de un "instrumento en lasca o lamina, con un borde astillado en forma continua y pareja, en ángulo oblicuo o abrupto. La forma del borde es generalmente convexa y pocas veces es recto o cóncavo" (Lavallée 1970: 18).

Estos artefactos posiblemente cumplieron la función de raspar las pieles o también madera u otros, como también pudo haber servido para alisar. Encontramos 28 raspadores (23 elaborados en obsidiana de color negro, 3 en cuarzo, 1 en arenisca y 1 en sílex). Estos fueron definidos en función de los ángulos de borde activo (usualmente superiores a los $50^{\circ}$, llegando hasta los $90^{\circ}$ ), las caras superiores presentan córtex, mientras que las caras inferiores generalmente son planas. El tipo de percusión utilizada en todos los casos es blanda.

\section{TIPOS DE RASPADORES}

Raspador Redondeado. Se trata de un raspador convexo, la zona funcional es redondeada. Se tiene en total 10 artefactos de este tipo elaborados en obsidiana (8), cuarzo (1) y sílex (1), el promedio de ángulos de borde activo es de $40^{\circ}$ a $80^{\circ}$. Presentan retoques. Todas las piezas fueron retocadas por percusión blanda, y el soporte es el bloque, solo algunos de estos tienen un soporte ya sean en lasca, lamina o bloque. El largo de estos artefactos varían de $3.6 \mathrm{~cm}$ a $1.9 \mathrm{~cm}$ de longitud, de $1.9 \mathrm{~cm}$ a $3.6 \mathrm{~cm}$ de ancho y de 0.5 a $1.4 \mathrm{~cm}$ de espesor (ver figura 41 ).

Raspador Triangular. Se trata de un raspador de forma triangular, la zona funcional es regularmente redondeada. Se tiene en total 2 artefactos de este tipo de raspador elaborados en obsidiana (1) y arenisca (1), el promedio de ángulos de borde activo es de $30^{\circ}$ a $60^{\circ}$. Presentan retoques. El largo de estos artefactos varían de $3.2 \mathrm{~cm}$ a $4.0 \mathrm{~cm}$ de longitud, de $2.2 \mathrm{~cm}$ a $3.8 \mathrm{~cm}$ de ancho y de 0.5 a $0.8 \mathrm{~cm}$ de espesor. Todas las piezas fueron retocadas por percusión blanda, y el soporte es una lámina y un bloque (ver figura 42).

Raspador Plano Convexo. Se trata de un raspador con la superficie ventral plana y por la presencia de dorso alto sin rebajar, la forma del borde activo es convexo. Se tiene en total 16 artefactos de este tipo, están elaborados en obsidiana (15) y cuarzo (1), el promedio de ángulos de borde activo es de $35^{\circ}$ a $90^{\circ}$. Presentan retoques. El largo de estos artefactos varían de $1.9 \mathrm{~cm}$ a $3.5 \mathrm{~cm}$ de longitud, de 1.9 $\mathrm{cm}$ a $3.0 \mathrm{~cm}$ de ancho y de 0.6 a $1.2 \mathrm{~cm}$ de espesor. Todas las piezas fueron retocadas por percusión blanda, y el soporte es el bloque y lasca, 9 de estos artefactos tienen retoque bifacial y 7 presentan solo retoque unifacial (ver figura 43).

PERFORADORES. Es un artefacto que ha sido hecho en un núcleo, lasca, lámina o astilla que se caracteriza por tener una punta delgada. Se trata de un: "Instrumento en lasca o lámina que presenta uno o más apéndices en punta. Uno de las funciones más probables para estos instrumentos es la de perforar cueros". (Lavallée 1970: 20).

Se cuenta en total con 19 artefactos de los cuales todos están elaborados en obsidiana, las medidas varían de $1.2 \mathrm{~cm}$ a $2.2 \mathrm{~cm}$ de largo, $0.9 \mathrm{~cm}$ a $1.7 \mathrm{~cm}$ de ancho y de $0.3 \mathrm{~cm}$ a $0.8 \mathrm{~cm}$ de espesor, el promedio de ángulos de borde activo es de $10^{\circ}$ a $25^{\circ}$. Presentan un retoque bifacial en toda la pieza, la distribución de los retoques es total, la extensión de los retoques varían, pueden ser: cortos, regulares, cubrientes o invasores; la forma de los retoques varían desde escamoso, paralelo y subparalelo. Todos estos artefactos se hicieron a presión y como soporte se tuvo una lámina (ver figura 44). 


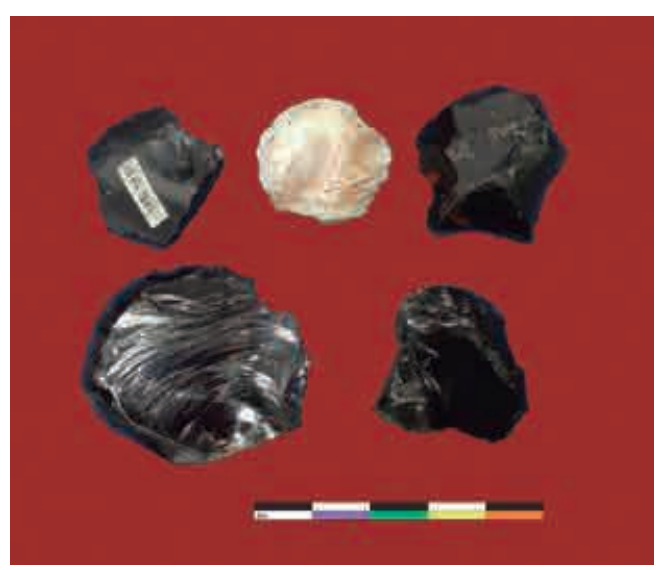

Figura 41: Raspador Redondeado.

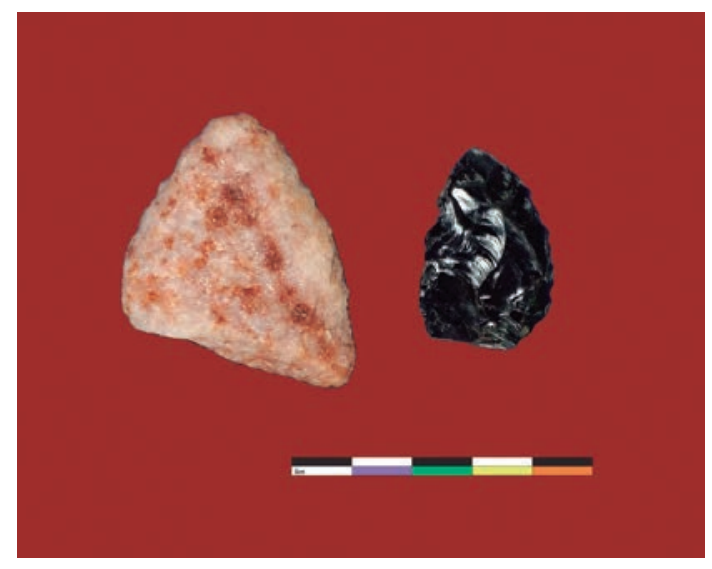

Figura 42: Raspadores Triangulares.

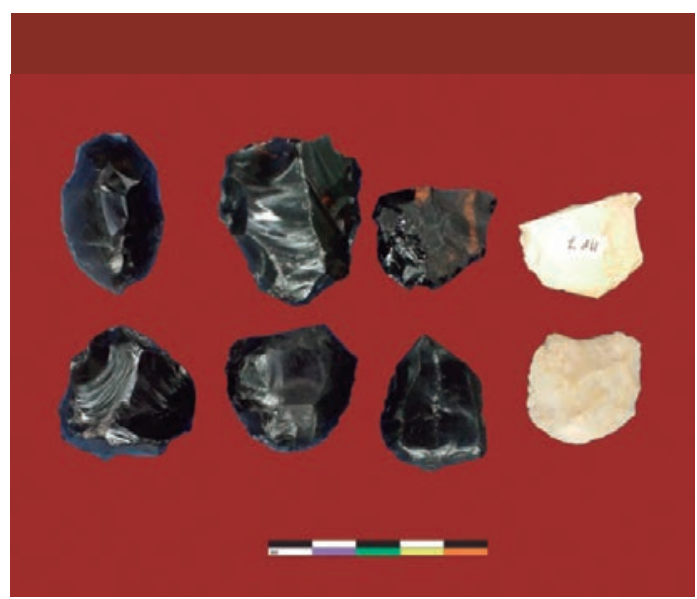

Figura 43: Raspador Plano Convexo.

\section{INSTRUMENTOS CON MUESCA}

Los instrumentos con muesca son artefactos pequeños que presentan muescas o depresiones generalmente cóncavas. "La muesca es una depresión, por lo general cóncava, con el borde interior modificado por astillamiento intencional o por uso" (Lavallée 1970: 20).

Estos instrumentos posiblemente sirvieron para cortar ya sean varas de madera o hueso ejerciendo una presión giratoria. Se cuenta en total con 02 artefactos elaborados en obsidiana, las medidas varían de $2.2 \mathrm{~cm}$ a $2.9 \mathrm{~cm}$ de largo, $1.5 \mathrm{~cm}$ a $1.8 \mathrm{~cm}$ de ancho y de $0.5 \mathrm{~cm}$ a $0.7 \mathrm{~cm}$ de espesor, el promedio de ángulos de borde activo es de $45^{\circ}$ a $50^{\circ}$. Presentan un retoque en ambas caras de la pieza, la distribución de los retoques es en el total de la pieza, los retoques cubren la pieza. Todos estos artefactos se hicieron a presión y como soporte se tuvo una lámina (ver figura 45).

DESECHOS DE TALLA. Los desechos de talla son fragmentos de lítico, que no presentan rastros de uso, son pequeños desperdicios obtenidos durante el proceso de talla o el proceso del debitage, 
no han sido usados como ningún artefacto. Los desechos de talla son fragmentos que no presentan rastros de uso, son pequeños desperdicios que se han obtenido durante el proceso de talla, estas no fueron usadas como instrumento. Un desecho de talla: “...no tiene las características de una lasca, de un núcleo o de un utensilio" (Chauchat 2006: 81).

Se tiene en total 354 fragmentos de desechos de talla, de las cuales 243 son de obsidiana de color negro, 31 son de obsidiana de color rojo, 12 son de basalto, 36 de cuarzo, 17 de arenisca, 7 de riolita, 8 de sílex. Estos fragmentos de desechos de talla son de diferentes formas, las medidas varían de $3.5 \mathrm{~cm}$ a $1.2 \mathrm{~cm}$ de largo, $3 \mathrm{~cm}$ a $1 \mathrm{~cm}$ de ancho y $0.8 \mathrm{~cm}$ a $0.3 \mathrm{~cm}$ de espesor (ver figura 46 y figura 47 ).

CANTOS RODADOS. Los cantos rodados son guijarros de roca dura que tienen la superficie lisa, fueron empleados sin ninguna modificación tienen las forma redondeada u oblonda por acción de agentes como herramienta para triturar o machacar, percutor, chancadores, pulidores o alisador.

Percutores. Se trata de instrumentos o en algunos casos, de artefactos, está destinado a percutir sobre un guijarro, un bloque, un núcleo, una preforma, y una herramienta de piedra tallada. También es un utensilio que se utiliza en la talla por percusión, para golpear una piedra con el objeto de dar forma a otro instrumento, también para poder devastar o retocar los artefactos líticos.

Se cuenta con 3 piezas en total, de las cuales 1 se encuentra fragmentada, la materia prima es el granito ligeramente rosado. Los 2 restantes son artefactos completos, que presentan huellas de desgaste, la materia prima de estos artefactos son granito uno de ellos y el otros se trata de una tectita, esto se identificó por la abundancia de silicatos que tiene y por la textura metálica que posee. Son de forma oblonda $u$ ovoide la superficie de estos instrumentos es rugosa con presencia de algunas estrías resultado de su uso (ver figura 49).

Alisadores. Los alisadores son cantos rodados pequeños, tienen la superficie pulida o alisada resultado de las actividades de alisar otros artefactos y herramientas. Se tiene 2 piezas de alisadores, la materia prima de estos artefactos son el granito de diferentes colores, ambos se encuentran fragmentados, la forma de estos son alargados. El largo varía de $10.9 \mathrm{~cm}$ a $5.4 \mathrm{~cm}$. (ver Figura 51).

Pulidores. Son pequeños artefactos que consisten en pequeños guijarros pulidos que presentan estrías en cualquiera de sus caras resultado de las actividades de pulimento. Se tiene 1 pieza, la materia prima es el granito, el artefacto esta integro, tiene una forma ovoide, presenta huellas de desgaste producto del pulimento. Su diámetro es de $3.5 \mathrm{~cm}$. (ver figura 50).

\section{CONCLUSIONES}

Qotamisa Pampa cumplió un rol muy importante para la supervivencia de los hombres que habitaron durante el Precerámico en este espacio, como muestra de estas actividades se tiene la presencia de una variedad de materiales líticos y la presencia de los talleres en donde fueron elaborados los útiles.

Las características medio ambientales permitieron la supervivencia de estos grupos, ya que estas características permitieron el desarrollo de los camélidos como también de algunos vegetales comestibles; además la cercanía para la obtención de la materia prima más usada en la elaboración de sus útiles, la cantera de obsidiana de Huancasancos.

Mediante el análisis detallado que se hizo de todos los materiales provenientes del sitio se llegó a determinar una tipología de puntas para esta zona, se separaron en total en 21 tipos de puntas, tomando en cuenta la forma y dimensión de los artefactos (criterios morfológicos), luego las técnicas 


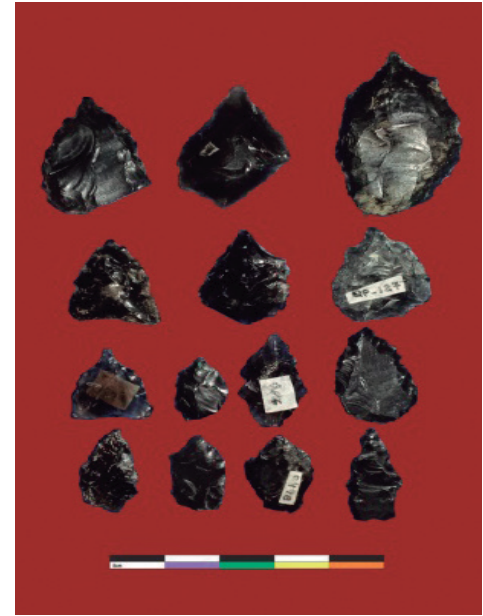

Figura 44: Perforadores elaborados en obsidiana.

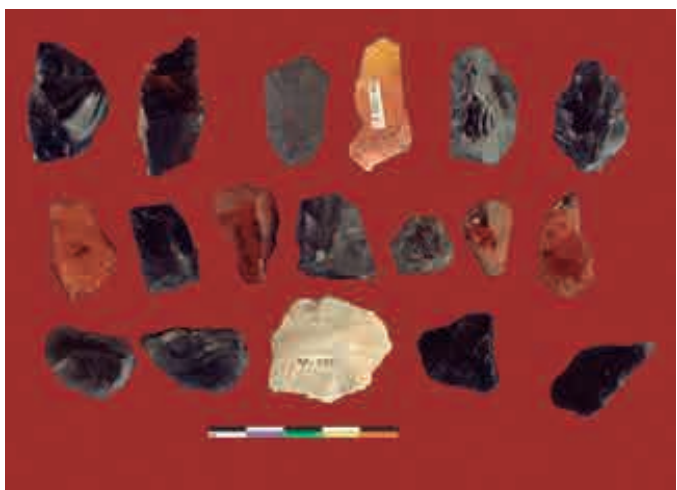

Figura 46: Desechos de talla de cuarzo, obsidiana, chert y basalto.

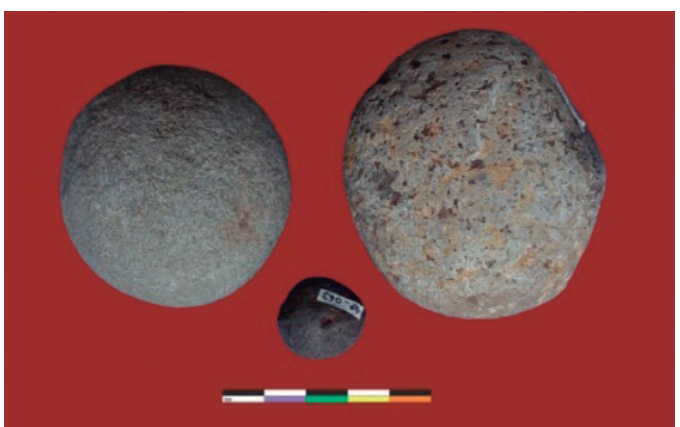

Figura 48: Cantos sin huellas de utilización.

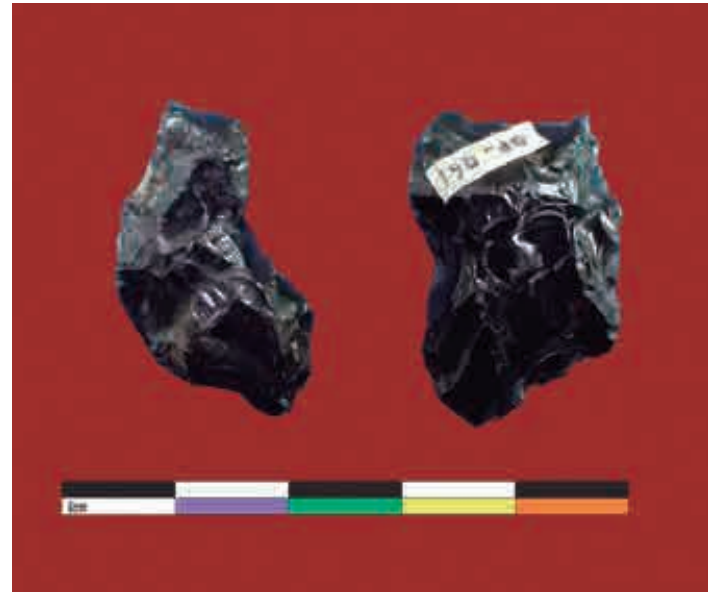

Figura 45: Instrumentos con muesca, elaborado en obsidiana.

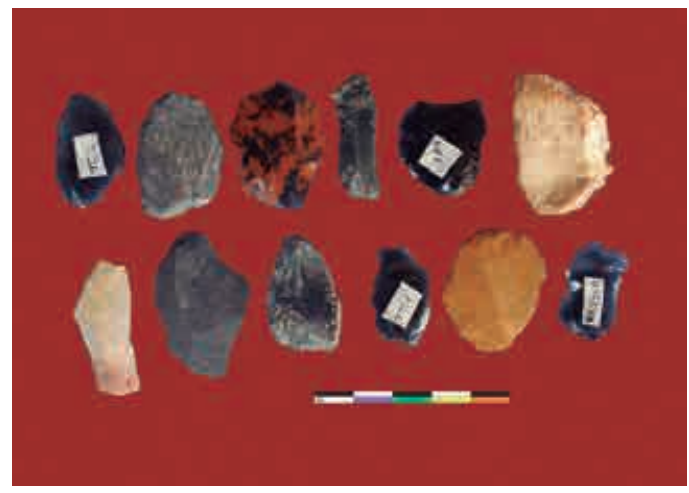

Figura 47: Desechos de talla de cuarzo, obsidiana, chert y basalto.

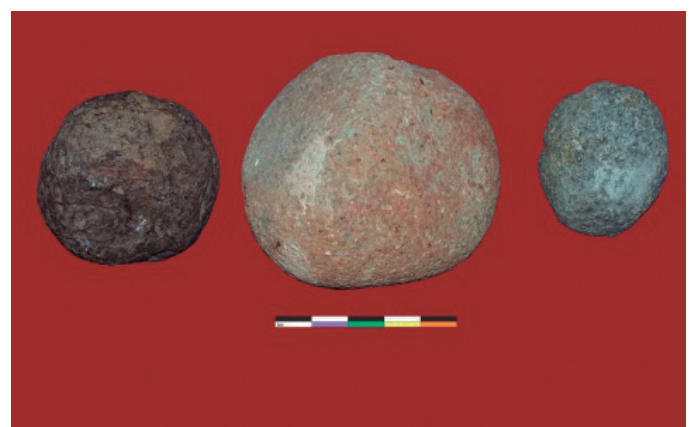

Figura 50: Pulidor en materia prima granito y tectita. 

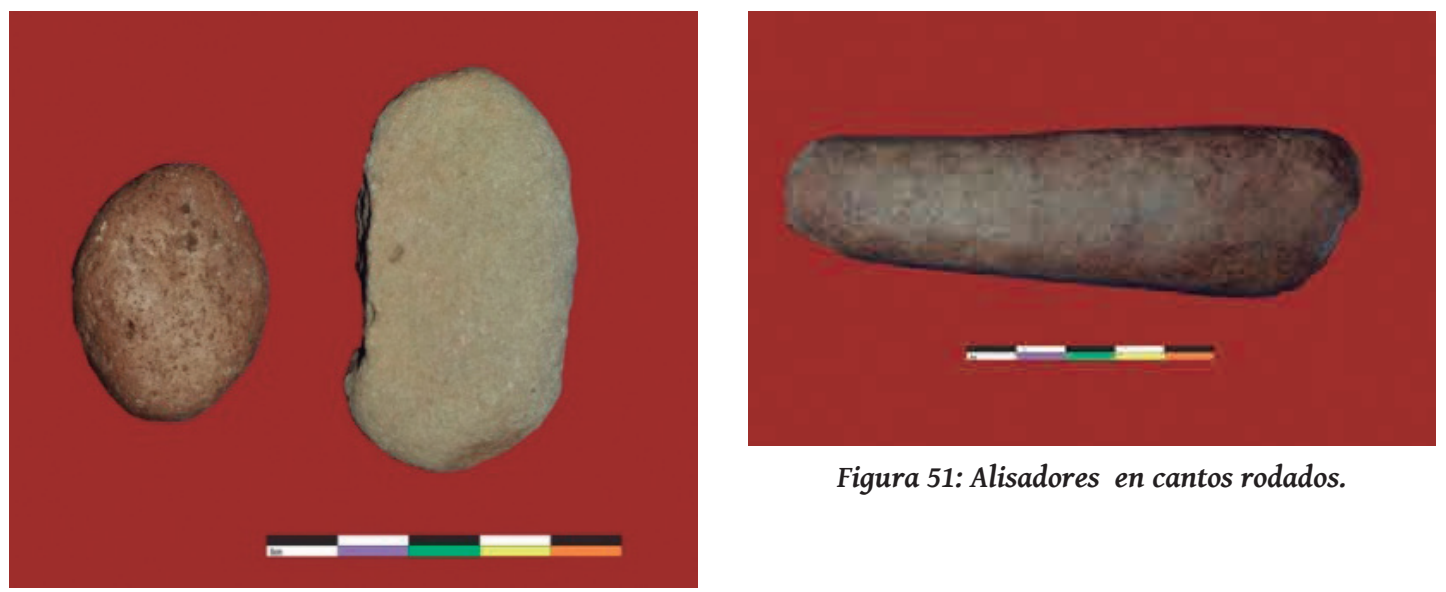

Figura 51: Alisadores en cantos rodados.

Figura 49: Percutor en materia prima granito.

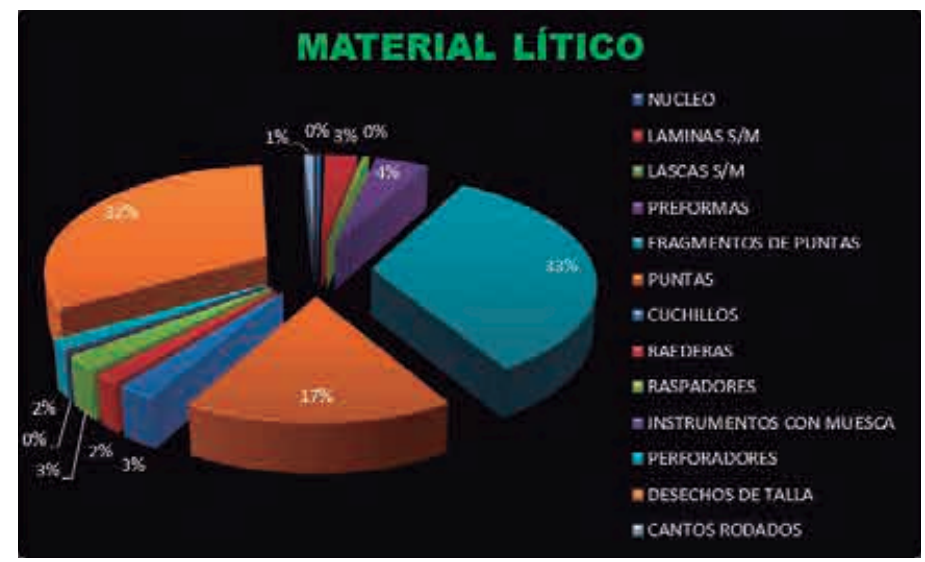

Figura 52: Cuadro de Porcentaje del Material Lítico.

de elaboración y la materia prima utilizada (criterios tecnológicos), la posible funcionalidad de cada uno de los materiales (Criterio Funcional) y la ubicación y distribución de cada uno de los materiales (Criterio Espacial o de ubicación).

Con el análisis de material de superficie recolectada del sitio de Qotamisa Pampa, se afirma que este tuvo una ocupación durante el Pre cerámico, ya que el 100\% del material cultural corresponde a materiales líticos correspondientes a estos periodos de ocupación.

Con los cuadros estadísticos obtenidos se afirma que la materia prima usada principalmente fue la obsidiana en un $86 \%$, seguido del cuarzo que se usó muy poco pero se tiene algunos artefactos elaborados en esta materia prima se tien (un 5\% del total del material), también se usó el basalto en un 4\% de todo el material analizado. De la misma manera se usaron otras materias primas se tiene un total del $5 \%$ de la muestra analizada, tales como la riolita, el granito y otros. 


\section{Agradecimientos}

Un especial agradecimiento a las personas quienes apoyaron durante los trabajos de campo, a Carina Paullo Mendoza y Keby Prado Flores. A Yuri Cavero por las sugerencias brindadas al momento de realizar el análisis de los materiales y por la información brindada.

\section{BiBLIOGRAFÍA}

CANCHARI HUAMANÍ, Khinjhe Maldini

2015 “Arquitectura de Raqaraqaypata Periodo Intermedio Tardío en Fajardo, Ayacucho”. En ALTERITAS Revista de Estudios Socioculturales Andino Amazónicos. Universidad Nacional de San Cristóbal de Huamanga. Ayacucho: Talleres Gráficos de la Imprenta Multiservicios PUBLIGRAF.

CASTILLO BENITES, Daniel S.

2006 Arte Rupestre en la Cuenca del Rio Chicama. Ediciones SIAN. Primera Edición. Trujillo.

CONTRERAS A., Daniel; TRIPCEVICH, Nicholas y CAVERO, Yuri I.

2012 “Investigaciones en la fuente de obsidiana tipo Qispisisaq, Hiancasancos-Ayacucho". Investigaciones Sociales Vol. 16, N²8. UNMSM. Lima.

CHAUCHAT, Claude

2006 Prehistoria de la Costa Norte del Perú: El Paijanense en Cupisnique. Instituto Francés de Estudios Andinos Patronato Huacas de Moche. Trujillo.

ECHEVERRÍA ALMEIDA, José

2011 Glosario de Arqueología y temas afines. Tomo I. Quito.

JUAN CABANILLES, Joaquín

2008 "El Utillaje de Piedra Tallada en La Prehistoria Reciente Valenciana: Aspectos tipológicos, estilísticos y evolutivos". Servicio de Investigación Prehistórica del Museo de Prehistoria de Valencia. Serie de trabajos Varios $\mathrm{N}^{\circ} 109$.

LAVALLÉE, Daniele

1970 “Industria Del Periodo Huaraz, Procedentes de Chavín de Huántar". Revista del Museo Nacional tomo XXXIV-Lima

MERINO SÁNCHEZ, José María

1994 “Tipología Lítica”. MUNIBE (Antropologia-Arkeologia). Suplemento N 9. Sociedad de Ciencias Aranzadi. 3ra edición.

SALCEDO CAMACHO, Luis E.

1997 Excavaciones en Cerro Tres Marías (Valle de Lurín): Un campamento temporal del Periodo Arcaico en las Lomas de Atocongo. Tesis para optar Título de Licenciado en Arqueología. Pontificia Universidad Católica del Perú. Lima- Perú.

SALAS VITANGURT, Dionisio

"En torno a la Civilización Ccarahuarina". Boletín de la Sociedad Geográfica de Lima. Tomo LVII. Lima, Perú. 


\section{VIVANCO POMACANCHARI, Cirilo}

1995 Arqueología de Puquio. Hacia la historia prehispánica. Monografía entregada a la Municipalidad de Puquio.

VIVANCO POMACANCHARI, Cirilo y MEDENS, Frank

2002-2005 “Confederacion Chanca: Mito Politico y realidad Arqueologica”. Xama 15-18. MendozaArgentina

VIVANCO POMACANCHARI, Cirilo; VALDEZ, Ernesto y PIZARRO, Antonio

2015 "Pobladores Prehispánicos Tardíos en Huamanquiquia, Fajardo-Ayacucho. El Ayllu Lukana en Qarachawayqo”. WARPA Revista Arqueológica № 15. Talleres Gráficos de la Imprenta Multiservicios PUBLIGRAF. Ayacucho- Huanta.

WINCHKLER, Giovanna

2006 Diccionario de uso para la descripción de objetos líticos. 